\title{
4
}

\section{TP53 Gene Polymorphisms in Cancer Risk: The Modulating Effect of Ageing, Ethnicity and TP53 Somatic Abnormalities}

\author{
Evgeny V. Denisov${ }^{1}$, Nadezhda V. Cherdyntseva', Nicolay V. Litviakov${ }^{1}$, \\ Elena A. Malinovskaya ${ }^{1}$, Natalya N. Babyshkina ${ }^{1}$, \\ Valentina A. Belyavskaya ${ }^{2}$ and Mikhail I. Voevoda ${ }^{3}$ \\ ${ }^{1}$ Cancer Research Institute, \\ Siberian Branch of Russian Academy of Medical Sciences, Tomsk, \\ ${ }^{2}$ Research Center of Virology and Biotechnology VECTOR, Koltsovo, \\ ${ }^{3}$ Institute of Internal Medicine, \\ Siberian Branch of Russian Academy of Medical Sciences, Novosibirsk, \\ Russian Federation
}

\section{Introduction}

The multi-talented "guardian of the genome" p53 is fundamental to preventing tumor development through the regulation of important cellular processes such as cell cycle arrest and senescence, DNA replication and repair, apoptosis, metabolism, antioxidant defense, and autophagy, among others. (Chumakov, 2007; Green and Kroemer, 2009; McCarthy, 2011; Olovnikov et al., 2009; Vousden and Prives, 2009; Vousden and Ryan, 2009). p53 protein is encoded by the TP53 gene (OMIM no. 191170), the structure of which is extremely variable in both healthy and diseased subjects, particularly in cancer, because of multiple germinal and somatic variations (Olivier et al., 2010; Whibley et al., 2009). Currently, approximately 85 polymorphisms and 27580 somatic mutations are known in the TP53 gene (Petitjean et al., 2007b). In addition, the TP53 gene, as a classic tumor suppressor, undergoes a loss of heterozygosity (LOH) and hypo- or hypermethylation (Brosh and Rotter, 2009; Sidhu et al., 2005; Soussi, 2007). From all polymorphisms found in the TP53 gene, three rs1042522, rs17878362, and rs1625895 - are well studied in terms of functional characterization, distribution in human populations and association with cancer risk. During the last 15 years, the predisposing value of these TP53 polymorphic variants has been estimated in relation to many human cancers; however, the data are inconsistent.

It is not surprising that cancer risk is a consequence of the interaction between constitutional genetics and environmental exposure. The combination of genetic background (gene-gene interactions) and environmental endo- and exogenous factors varies among individuals of different ethnical groups and might explain the distinct tumor susceptibility. Cancer is an extremely complicated phenotype and, together with the incomplete penetrance of the inherited tumor risk alleles, interaction with environmental risk factors could substantially alter hereditary susceptibility (Perez-Losada et al., 2011). Nutritional aspects, reproductive 
factors, and alcohol, smoking, and radiation along with other exposures may considerably influence the genetic background via genotoxic effects or the activation/inhibition of major pathways and modify cancer susceptibility. This statement is especially true of TP53, the functionality of which has inducible character and depends on environmental exposure. Additionally, cancer arises as a result of the stepwise accumulation of genetic mutations, chromosomal aberrations and epigenetic alterations (Hanahan and Weinberg, 2011; Marshall, 1991). Thus, TP53 polymorphisms may define the sequence of mutational events, as previously demonstrated (Denisov et al., 2011; Hrstka et al., 2009; Litviakov et al., 2010; Whibley et al., 2009). Even more importantly, the manifestation of functional roles of TP53 polymorphisms is tissue- and age-specific, meaning that their effect on p53-controlled processes may vary between cell types and age groups (Azzam et al., 2011; Bonafe et al., 2004; Salvioli et al., 2005). Based on the above reasoning, a simultaneous account of TP53 polymorphisms and their tissue- and age-specific effects, along with ethnicity-specific genetic background and environmental exposure, may reveal how TP53 germline variations modify cancer risk. In this review, we focus on the recent findings regarding TP53 polymorphisms, rs1042522, rs17878362, and rs1625895, their functional role and association with cancer risk, their relationships with environmental exposure and somatic aberrations in tumors, as well as discuss some hypotheses explaining the present contradictions in the biological role of TP53 variations in cancer.

\section{Functional TP53 polymorphisms and cancer risk}

\subsection{TP53 polymorphisms: The functional value}

The TP53 rs1042522 (Ex4+119C>G: C and G alleles) polymorphism displays substitution of $\mathrm{C}$ to $\mathrm{G}$ in codon 72 of exon 4 of the TP53 gene, changing the amino acid from proline (Pro) to arginine (Arg) in the proline-rich domain of p53 protein (Harris et al., 1986). p53 forms p53Pro and p52Arg are characterized by molecular differences in protein structure (Table 1); however, the data are contradictory and inconclusive (Naldi et al., 2010; Ozeki et al., 2011; Thomas et al., 1999). In addition, there is no final opinion concerning the influence of TP53 rs1042522 polymorphism on the p53 mRNA level (Nikbahkt Dastjerdi, 2011; Ribeiro et al., 1997; Siddique et al., 2005; Wang et al., 1999). Further, it is beyond any doubt that p53Pro and p53Arg differ in their capability to regulate p53-dependent cell processes (Table 1). Many thousands of years ago, precisely such p53 functional differentiation was the reason for dramatic changes in the proportion of rs1042522 alleles from equatorial areas to northern latitudes (Beckman et al., 1994; Sjalander et al., 1996). In particular, the rs1042522 C allele is the ancestral form with $\sim 60-95 \%$ frequency in African populations, whereas the G allele arose some 30,000 to 50,000 years ago and increased in percentage as populations migrated farther north, where its allele frequency reached 75-85\% (Hirshfield et al., 2010; Jeong et al., 2010). The most likely components of evolutionary selection pressure fixing TP53 alleles into these geographic regions are implantation and reproduction, as well as sunburn resistance (Hirshfield et al., 2010; Hu et al., 2011; Jeong et al., 2010), the antithetic regulation of which has been demonstrated for p53 rs1042522 protein forms (Table 1). Specifically, the rs $1042522 \mathrm{G}$ allele exhibits 2-fold higher transcriptional activity toward the LIF gene, which encodes a cytokine that is required for optimal implantation and reproduction, compared with the C allele (Feng et al., 2011; Jeong et al., 2010; Kang et al., 2009). 


\begin{tabular}{|c|c|c|c|c|c|c|c|}
\hline & \multicolumn{6}{|c|}{ p53 protein forms } & \multirow{3}{*}{ Ref. } \\
\hline & \multicolumn{2}{|c|}{ rs1042522 } & \multicolumn{2}{|c|}{ rs17878362 } & \multicolumn{2}{|c|}{ rs1625895 } & \\
\hline & $\mathrm{G}$ & $\mathrm{C}$ & A1 & A2 & G & $\mathrm{A}$ & \\
\hline \multirow{2}{*}{$\begin{array}{l}\text { p53 protein } \\
\text { structure }\end{array}$} & \multicolumn{2}{|c|}{ Identical } & \multirow{2}{*}{\multicolumn{2}{|c|}{$\begin{array}{c}\text { Altered } \\
\text { topology of G- } \\
\text { quadruplexes } \\
\text { in intron } 3 \\
\end{array}$}} & \multirow{2}{*}{ - } & & (Marcel et al., 2011; \\
\hline & \multicolumn{2}{|c|}{ Different } & & & & & $\begin{array}{l}\text { Ozeki et al., 2011; } \\
\text { Thomas et al., 1999) }\end{array}$ \\
\hline \multirow{2}{*}{ p53 mRNA level } & High & Low & \multirow{2}{*}{ High } & \multirow{2}{*}{ Low } & \multirow{2}{*}{-} & \multirow[b]{2}{*}{-} & $\begin{array}{l}\text { (Gemignani et al., } \\
\text { 2004; Nikbahkt }\end{array}$ \\
\hline & \multicolumn{2}{|c|}{ Identical } & & & & & $\begin{array}{l}\text { Dastjerdi, 2011; } \\
\text { Ribeiro et al., 1997; } \\
\text { Siddique et al., 2005) }\end{array}$ \\
\hline \multicolumn{8}{|l|}{ Capability to } \\
\hline transactivation & Low & High & - & - & - & - & $\begin{array}{l}\text { (Frank et al., 2011; } \\
\text { Thomas et al., 1999) }\end{array}$ \\
\hline cell cycle arrest & Low & High & - & - & - & - & $\begin{array}{l}\text { (Frank et al., 2011; } \\
\text { Pim and Banks, 2004) }\end{array}$ \\
\hline $\begin{array}{l}\text { senescence } \\
\text { induction }\end{array}$ & Low & High & - & - & - & - & $\begin{array}{l}\text { (Frank et al., 2011; } \\
\text { Salvioli et al., 2005) }\end{array}$ \\
\hline DNA repair & Low & High & High & Low & High & Low & $\begin{array}{l}\text { Siddique and } \\
\text { Sabapathy, 2006; } \\
\text { Wu et al., 2002) }\end{array}$ \\
\hline $\begin{array}{l}\text { genomic } \\
\text { stability } \\
\text { maintenance }\end{array}$ & Low & High & - & - & High & Low & $\begin{array}{l}\text { (Litviakov et al., 2010; } \\
\text { Qiu et al., 2008; } \\
\text { Schwartz et al., 2011; } \\
\text { Siddique and } \\
\text { Sabapathy, 2006) }\end{array}$ \\
\hline \multicolumn{8}{|l|}{$\begin{array}{l}\text { apoptosis } \\
\text { activation }\end{array}$} \\
\hline $\begin{array}{l}\text { in extrinsic } \\
\text { pathway }\end{array}$ & Low & High & \multirow[t]{2}{*}{ High } & \multirow[t]{2}{*}{ Low } & \multirow[t]{2}{*}{ High } & \multirow[t]{2}{*}{ Low } & \multirow{2}{*}{$\begin{array}{l}\text { (Bendesky et al., } \\
\text { 2007; Biros et al., } \\
\text { 2002; Bonafe et al., } \\
\text { 2002; Dumont et al., } \\
\text { 2003; Pim and } \\
\text { Banks, 2004; } \\
\text { Schneider-Stock et } \\
\text { al., 2004b; Siddique } \\
\text { and Sabapathy, 2006; } \\
\text { Wu et al., 2002) }\end{array}$} \\
\hline $\begin{array}{l}\text { in intrinsic } \\
\text { pathway }\end{array}$ & High & Low & & & & & \\
\hline $\begin{array}{l}\text { suppression of } \\
\text { transformed } \\
\text { cell growth }\end{array}$ & High & Low & - & - & - & - & (Thomas et al., 1999) \\
\hline $\begin{array}{l}\text { survival in } \\
\text { hypoxia }\end{array}$ & High & Low & - & - & - & - & \multirow{2}{*}{$\begin{array}{l}\text { (Sansone et al., 2007; } \\
\text { Vannini et al., 2008) }\end{array}$} \\
\hline $\begin{array}{l}\text { induction of cell } \\
\text { death in hypoxia }\end{array}$ & Low & High & - & - & - & - & \\
\hline
\end{tabular}




\begin{tabular}{|c|c|c|c|c|c|c|c|}
\hline $\begin{array}{l}\text { cell-cell } \\
\text { adhesion } \\
\text { activation }\end{array}$ & High & Low & - & - & - & - & (Jeong et al., 2010) \\
\hline reproduction & High & Low & - & - & - & - & $\begin{array}{l}\text { (Feng et al., 2011; } \\
\text { Jeong et al., 2010; } \\
\text { Kang et al., 2009; } \\
\text { Kay et al., 2006) }\end{array}$ \\
\hline \multicolumn{8}{|l|}{$\begin{array}{l}\text { degradation } \\
\text { mediated by }\end{array}$} \\
\hline $\begin{array}{l}\text { E6 } \\
\text { oncoprotein }\end{array}$ & High & Low & - & - & - & - & (Storey et al., 1998) \\
\hline \multirow{2}{*}{$\begin{array}{l}\text { MDM2 } \\
\text { ubiquitin } \\
\text { ligase }\end{array}$} & High & Low & \multirow{2}{*}{ - } & \multirow{2}{*}{-} & \multirow{2}{*}{-} & \multirow{2}{*}{-} & \multirow{2}{*}{$\begin{array}{l}\text { (Dumont et al., 2003; } \\
\text { Ozeki et al., 2011) }\end{array}$} \\
\hline & Low & High & & & & & \\
\hline sunburn & High & Low & - & - & - & - & $\begin{array}{l}\text { (McGregor et al., } \\
\text { 2002; Pezeshki et al., } \\
2006)\end{array}$ \\
\hline
\end{tabular}

Table 1. Structural and functional characteristics of p53 proteins encoded by TP53 (rs1042522, rs17878362 and rs1625895) polymorphisms.

Moreover, the $\mathrm{C}$ allele was found to be increased in women with recurrent implantation failure and individuals undergoing in vitro fertilization (IVF), and is a risk factor for implantation failure after IVF (Kang et al., 2009; Kay et al., 2006). Interestingly, the frequency of the $G$ allele has been positively correlated with low winter temperatures (Shi et al., 2009). In this respect, northern populations living in cold climates and having a high percentage of $\mathrm{G}$ alleles could be at an advantage due to a reduced risk of implantation failure (Feng et al., 2011; Hu et al., 2011). Additionally, it is critical to note that the geographic distribution of rs1042522 alleles is also linked with the capacity of p53 to regulate pigmentation and sunburn resistance through the activation of tyrosinase, the ratelimiting enzyme for melanin synthesis, and by induction of transcription of the melanogenic cytokine pro-opiomelanocortin (Hirshfield et al., 2010; Khlgatian et al., 2002; Murase et al., 2009). Accordingly, one may reasonably suppose that the p53-dependent stimulation of pigmentation could be a protective mechanism from UV light for light-skinned populations. Previously, a significant positive association between the $G$ allele and susceptibility to sunburn was demonstrated (McGregor et al., 2002; Pezeshki et al., 2006), whereas the C allele was most prevalent in dark-skinned races originating from areas with high ambient UV levels (McGregor et al., 2002).

It should not be forgotten that one of the main functions of TP53 is the maintenance of genomic stability through the removal of genetically aberrant cells and the suppression of tumor development. Different abilities concerning induction cell cycle arrest, DNA repair, and senescence, the activation of apoptosis and the suppression of transformed cell growth, and survival in hypoxia have been observed for the p53 protein encoded by alleles with TP53 rs1042522 polymorphism (Table 1). As compared to p53Arg, p53Pro protein (C allele) is the best transactivation molecule (Frank et al., 2011; Thomas et al., 1999) and displays a high capability to block the cell cycle (Frank et al., 2011; Pim and Banks, 2004), induce DNA repair (Siddique and Sabapathy, 2006), remove micronuclei (Siddique and Sabapathy, 2006) 
and chromosome aberrations (Litviakov et al., 2010; Schwartz et al., 2011), and stimulate cell senescence (Frank et al., 2011; Salvioli et al., 2005) and cell death in hypoxic environments via activation/inhibition of p53-target genes such as p21, p53R2, p48, GADD45, PAI-1 and the hypoxia response genes. In contrast, p53Arg protein induces apoptosis markedly better and with faster kinetics than p53Pro but mainly through intrinsic pathways and a significant ability to activate the DR-4, NOXA, PUMA, PIG-3, and PERP genes, localize to the mitochondria and release cytochrome C into the cytosol (Dumont et al., 2003; Jeong et al., 2010; Pim and Banks, 2004; Thomas et al., 1999; Zhu et al., 2010). However, the strongly pronounced apoptotic ability of p53Arg does not protect against the process of carcinogenesis (Zhu et al., 2010). Likewise, p53Arg is more efficient than p53Pro in the suppression of transformed cell growth by the E7 and EJ-ras oncogenes and survival in hypoxia (Thomas et al., 1999; Vannini et al., 2008). Curiously, tumors of the head and neck losing the $\mathrm{C}$ and bearing the $\mathrm{G}$ allele show a lack of co-expression of Fas/FasL and high expression of $\mathrm{Bcl} 2$ proteins, and, as a consequence, markedly reduced apoptosis (SchneiderStock et al., 2004b). Simply stated, p53Pro protein seems to be the best inductor of apoptosis in the extrinsic pathway. This also results from the fact that p53Pro, but not p53Arg, along with NF-kB, transactivates caspase 4/11, an important component of the extrinsic pathway in apoptosis induction (Azzam et al., 2011; Frank et al., 2011). Aside from the abovementioned data, it was recently established that the TP53 rs1042522 polymorphism impacts the apoptotic function of p53 in a tissue-specific manner. Specifically, p53Pro protein more effectively activates programmed cell death in thymus (Frank et al., 2011), whereas in the small intestine, apoptosis is significantly higher in G-expressing cells (Azzam et al., 2011; Zhu et al., 2010). Interestingly, in the spleen, there was no difference in the induction of apoptosis between rs1042522 variants (Azzam et al., 2011). Taken together, the tumorsuppressing function of p53 is considerably modified by TP53 rs1042522 polymorphism, while the effect of p53 allelic variants on tumor growth, mainly manifested in apoptosis regulation, depends on the genetic and tissue-specific background.

p53 is a multifaceted and multifunctional molecule with implications in a majority of cell processes. There is growing evidence that p53 is involved in regulation of the epithelialmesenchymal transition (EMT) and cell phenotype, as well as cell migration and invasion (Muller et al., 2011). Breast and lung cancers with p53 mutations exhibit stem cell-like transcriptional patterns and are depleted in terms of the activity of differentiation genes (Mizuno et al., 2010). Furthermore, a loss of p53 leads to decreased expression of microRNA miR-200c, stimulated expression of EMT and stemness markers, and the development of high tumor grades in a cohort of breast tumors (Chang et al., 2011). Interestingly, p53 mutants with gain of novel function enhanced the efficiency of the reprogramming process compared with p53 deficiency (Sarig et al., 2010). As recently published by Jeong et al. (Jeong et al., 2010), TP53 rs1042522 polymorphism may modify cell-cell adhesion, particularly through the high capability of p53Arg protein to induce expression of the PERP gene (Table 1). Additionally, p53Arg possesses the best ability to activate $C H M P 4 C$, a member of the EMT family of genes.

In comparison with TP53 rs1042522 polymorphism, rs17878362 and rs1625895 variations are poorly characterized in terms of structural and functional properties. However, the current data are sufficiently convincing of significant influence on p53 activity. The TP53 rs17878362 polymorphism consists of a 16 bp duplication in intron 3 (PIN3: A1, non-duplicated allele and A2, duplicated allele). In a series of previous studies, it was demonstrated that the presence of the rs17878362 minor allele (A2) results in decreasing p53 mRNA levels, intensity of DNA repair and apoptosis processes (Table 1) (Gemignani et al., 2004; Wu et al., 
2002). In addition, there is an opinion that TP53 rs17878362 polymorphism may alter the topology of G-quadruplexes in intron 3, regulating the alternative splicing of intron 2, thus modulating the patterns of expression of transcripts encoding either p53 or its N-terminally truncated isoform, $\Delta 40$ p53 (Marcel et al., 2011). With respect to rs1625895 (IVS6+62A>G: A and $G$ alleles), this polymorphism displays an $A>G$ transversion and, according to literature data, is responsible for changes in the induction of DNA repair and apoptosis and the maintenance of genomic stability (Table 1) (Qiu et al., 2008; Wu et al., 2002). It should be pointed out that TP53 rs1625895 and rs17878362 polymorphisms are in perfect linkage disequilibrium with rs1042522 (Sjalander et al., 1995; Weston et al., 1997) and, most likely, these intronic variations control the alternative splicing and mRNA level of p53Arg and p53Pro proteins. Consequently, it would be logical to take into account the TP53 linkage disequilibrium box in disease pathogenesis studies.

\subsection{TP53 polymorphisms: The cancer predisposing value}

Owing to the importance of p53 in tumor suppression, TP53 rs1042522, rs17878362, and rs1625895 polymorphisms altering p53 functionality might affect cancer risk (Whibley et al., 2009). The results of the consortium works and last meta-analyses, demonstrating the predisposing value of TP53 germline variations in different types of human cancer, are overviewed in Table 2. It should be immediately noticed that in a majority of cancers, the data are inconclusive, and further studies are needed to clarify the associations. In addition, there are certain annoying mistakes in some meta-analyses, which result in entirely noncredible data, and it would be valuable to provide a new, more accurate estimation of association of TP53 polymorphisms with cancer risk (Economopoulos and Sergentanis, 2010; Lu et al., 2011a; Lu et al., 2011b; Lu et al., 2011c; Sergentanis and Economopoulos, 2010a, 2011). However, in spite of the present disagreements and methodological flaws, association tendencies for some cancer localizations are clear (Table 2). Simply stated, the rs1042522 C allele is associated with increased susceptibility to cancers, including of the lung (Dai et al., 2009; Francisco et al., 2010; Li et al., 2009; Yan et al., 2009), head and neck (Francisco et al., 2010), thyroid (Francisco et al., 2010), esophagus (Wang et al., 2010a; Zhao et al., 2010), pancreas (Liu et al., 2011), liver (Chen et al., 2011; Francisco et al., 2010), gallbladder (Liu et al., 2011), nasopharynx (Zhuo et al., 2009b), and cervix (Francisco et al., 2010; Klug et al., 2009). No significant contribution of TP53 rs1042522 polymorphism to oral cancer has been reported (Zhuo et al., 2009c). A high heterogeneity of results was observed in breast (He et al., 2011; Hu et al., 2010b; Lu et al., 2011b; Ma et al., 2011; Peng et al., 2011; Sergentanis and Economopoulos, 2010b; The Breast Cancer Association Consortium, 2006; Zhang et al., 2010b; Zhuo et al., 2009a), colon and rectum (Dahabreh et al., 2010; Economopoulos and Sergentanis, 2010; Economopoulos et al., 2010; Liu et al., 2011; Tang et al., 2010; Wang et al., $2010 \mathrm{~b}$ ) cancers. Though still not quite clear, cancer of the ovary (Schildkraut et al., 2009; Zhang et al., 2008), endometrium (Francisco et al., 2010; Jiang et al., 2010b), stomach (Francisco et al., 2010; Gao et al., 2009; Liu et al., 2011), bladder (Jiang et al., 2010a; Li et al., 2010), prostate (Zhang et al., 2010a; Zhang et al., 2011b; Zhu et al., 2011), and skin (Francisco et al., 2010; Jiang et al., 2011) appear to be affected. As for the rs17878362 polymorphism, a clear association of the A2 allele with a high risk of breast cancer (He et al., 2011; Hu et al., 2010a; Hu et al., 2010b; Zhang et al., 2011a) and a lack of involvement in lung (Hu et al., 2010a), ovary (Schildkraut et al., 2009), colon and rectum (Hu et al., 2010a) cancer susceptibility has been demonstrated. Interestingly, Peng et al. (Peng et al., 2011) did not show a dependence of breast cancer development on rs17878362 germline variation. For the 
rs1625895 polymorphism, no association with breast (He et al., 2011; Hu et al., 2010b) or ovary (Schildkraut et al., 2009) cancers has been presented in the available literature.

Cancer is a heterogeneous polygenic disorder with a well-established gene environment playing an important role in disease etiology (Hanahan and Weinberg, 2011; Perez-Losada et al., 2011). The significant heterogeneity of the associative value of TP53 polymorphisms, especially rs 1042522 variation, among human cancers is most likely explained by specific p53 inducible functionality essentially depending on ethnicity-related genetic background and environmental exposure, tissue and age specificity (Azzam et al., 2011; Chung et al., 2010; Donehower, 2006; Francisco et al., 2010; van Heemst et al., 2005). The complex of lifestyle endo- and exogenous factors of each ethnic group, the proportion of which increases with age, may dramatically modulate the contribution of TP53 polymorphisms to cancer risk through, for example, genotoxic effects and epigenetic modifications of the TP53 gene structure. Exogenous modifiable factors, such as alcohol, smoking and betel or areca quid chewing, and radiation and chemical poisoning, together with endogenous estrogen metabolites and other secreted chemicals, have been found to be involved in DNA damage and epigenetic alterations (De Bont and van Larebeke, 2004; Hsu et al., 2010; Seviour and Lin, 2010). In this case, TP53 functionally different polymorphisms serving as background for origin of TP53 abnormalities, such as mutations and a loss of heterozygosity $(\mathrm{LOH})$, promote neoplastic transformation by switching off p53-dependent control of genomic stability and further accumulation of genetic damage (Denisov et al., 2011). As a classic tumor suppressor, TP53 inactivation seems to underlie Knudson's "two-hit" model supposing that two mutations or "hits" (point mutation and loss of allele, producing $\mathrm{LOH}$ ) are required to inactivate genes and cause cancer or promote disease progression (Knudson, 1971); however, there are tumors that are exceptions to this rule (Donehower and Lozano, 2009; Thiagalingam et al., 2002). Nevertheless, the simultaneous presence of mutations and LOH in the TP53 gene is a widespread phenomenon in human cancer, suggesting that one inactivation is not sufficient to completely inactivate p53 (Baker et al., 1990; Nigro et al., 1989).

\begin{tabular}{|c|c|c|c|c|}
\hline Cancers & rs1042522 & rs17878362 & rs1625895 & Ref. \\
\hline \multirow{5}{*}{ Breast } & no & no & - & $\begin{array}{l}\text { (Ma et al., 2011; Peng et } \\
\text { al., 2011; The Breast } \\
\text { Cancer Association } \\
\text { Consortium, 2006; Zhuo } \\
\text { et al., 2009a) }\end{array}$ \\
\hline & $C \downarrow$, Mediterraneans & $\mathrm{A} 2 \uparrow$ & no & $\begin{array}{l}\text { (Hu et al., 2010a; Hu et } \\
\text { al., 2010b) }\end{array}$ \\
\hline & $\mathrm{G} \uparrow$ & - & - & $\begin{array}{l}\text { (Lu et al., 2011b; } \\
\text { Sergentanis and } \\
\text { Economopoulos, 2010b; } \\
\text { Zhang et al., 2010b) }\end{array}$ \\
\hline & $\mathrm{G} \uparrow$, Indians & $\mathrm{A} 2 \uparrow$ & no & (He et al., 2011) \\
\hline & no & A $2 \uparrow$ & - & (Zhang et al., 2011a) \\
\hline $\begin{array}{l}\text { Lung, head and } \\
\text { neck, thyroid }\end{array}$ & $\mathrm{C} \uparrow$ & no & - & $\begin{array}{l}\text { (Dai et al., 2009; } \\
\text { Francisco et al., 2010; } \\
\text { Hu et al., 2010a; Li et al., } \\
\text { 2009; Truong et al., 2010; } \\
\text { Yan et al., 2009) }\end{array}$ \\
\hline
\end{tabular}




\begin{tabular}{|c|c|c|c|c|}
\hline \multicolumn{5}{|l|}{ Gynecologic } \\
\hline \multirow{2}{*}{ Ovary } & no & no & no & (Schildkraut et al., 2009) \\
\hline & $\mathrm{C} \downarrow$ & - & - & (Zhang et al., 2008) \\
\hline \multirow{2}{*}{ Cervix } & $\mathrm{G}^{* *}$ & - & - & (Klug et al., 2009) \\
\hline & $C \downarrow$ & - & - & (Francisco et al., 2010) \\
\hline \multirow{2}{*}{ Endometrium } & no & - & - & (Jiang et al., 2010b) \\
\hline & $\mathrm{C} \uparrow$ & - & - & (Francisco et al., 2010) \\
\hline \multicolumn{5}{|l|}{ Digestive tract } \\
\hline Oral cavity & no & - & - & (Zhuo et al., 2009c) \\
\hline \multirow{3}{*}{ Stomach } & $C \uparrow$ & - & - & $\begin{array}{l}\text { (Francisco et al., 2010; } \\
\text { Liu et al., 2011) }\end{array}$ \\
\hline & $\begin{array}{c}\mathrm{C} \uparrow, \text { diffuse type, } \\
\text { Asians }\end{array}$ & \multirow{2}{*}{-} & \multirow{2}{*}{-} & \multirow{2}{*}{ (Gao et al., 2009) } \\
\hline & $\begin{array}{c}C \downarrow, \text { intestinal type, } \\
\text { Caucasians }\end{array}$ & & & \\
\hline $\begin{array}{l}\text { Esophagus, } \\
\text { pancreas, } \\
\text { liver, } \\
\text { gallbladder }\end{array}$ & $\mathrm{C} \uparrow$ & - & - & $\begin{array}{l}\text { (Chen et al., 2011; } \\
\text { Francisco et al., 2010; Liu } \\
\text { et al., 2011; Wang et al., } \\
\text { 2010a; Zhao et al., 2010) }\end{array}$ \\
\hline \multirow{4}{*}{$\begin{array}{l}\text { Colon and } \\
\text { rectum }\end{array}$} & no & no & - & $\begin{array}{l}\text { (Economopoulos and } \\
\text { Sergentanis, 2010; Hu et } \\
\text { al., 2010a; Tang et al., } \\
\text { 2010; Wang et al., 2010b) }\end{array}$ \\
\hline & $\begin{array}{l}\mathrm{C} \downarrow \text {, Caucasians } \\
\text { (tendency) }^{\dagger}\end{array}$ & - & - & $\begin{array}{l}\text { (Economopoulos et al., } \\
2010 \text { ) }\end{array}$ \\
\hline & $\mathrm{C} \downarrow^{*}$ & - & - & (Dahabreh et al., 2010) \\
\hline & $\mathrm{C} \uparrow$ & - & - & (Liu et al., 2011) \\
\hline $\begin{array}{l}\text { Total group } \\
\text { without oral } \\
\text { cavity }\end{array}$ & $\mathrm{C} \uparrow$, Asians & - & - & (Liu et al., 2011) \\
\hline \multirow{2}{*}{ Bladder } & $\mathrm{G} \uparrow$, Caucasians & - & - & (Li et al., 2010) \\
\hline & $G \downarrow$, Asians & - & - & (Jiang et al., 2010a) \\
\hline Nasopharynx & $\mathrm{G} \downarrow, \mathrm{C} \uparrow$ & - & - & (Zhuo et al., 2009b) \\
\hline \multirow{3}{*}{ Prostate } & no & - & - & (Zhu et al., 2011) \\
\hline & 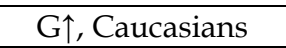 & - & - & (Zhang et al., 2010a) \\
\hline & $\mathrm{C} \downarrow \neq$ & - & - & (Zhang et al., 2011b) \\
\hline \multirow{2}{*}{ Skin } & no & - & - & (Jiang et al., 2011) \\
\hline & $C \downarrow$ & - & - & (Francisco et al., 2010) \\
\hline
\end{tabular}

allele increases cancer risk. $\downarrow$ allele decreases cancer risk.

*only in non-epidemiological studies and studies, where controls were not in Hardy-Weinberg equilibrium and polymorphism analysis was determined from tumor tissue. tin studies where controls did not deviate from the Hardy-Weinberg equilibrium. *in population-based control subjects.

Table 2. The association of TP53 gene polymorphisms with human cancers (data from the consortium works and the last meta-analyses). 


\subsection{TP53 polymorphisms: The background for TP53 abnormalities}

TP53 gene mutations, represented by specific single monoallelic missense aberrations, are "universal" genetic abnormalities in human tumors, with a frequency varying from 10 to close to 100\% (Brosh and Rotter, 2009; Olivier et al., 2010; Rivlin et al., 2011). TP53 mutants display a loss of transactivation capability via conformational changes in p53 protein structure, as well as gain-of-function effects through the activation of multidrug resistance genes ( $A B C B 1, A B C C 1, A B C G 1$, and $M V P)$, growth factor receptor genes (EGFR, $b F G F$, and $V E G F)$, oncogenes (c-Myc, c-Fos, and Ras) or via the inhibition of paralogs p63 and p73, which are responsible for the induction of apoptosis (Brosh and Rotter, 2009; Olivier et al., 2010; Oren and Rotter, 2010). Due to tumor-promoting effects, TP53 mutations have been shown to contribute to poor prognosis and therapeutic effectiveness in a majority of cancers (Brosh and Rotter, 2009; Olivier et al., 2010; Petitjean et al., 2007a). Despite the high TP53 mutability, there is data concerning the presence of alternative inactivation pathways through the methylation of CG repeats in the TP53 gene (Almeida et al., 2009; Amatya et al., 2005; Kang et al., 2001; Sidhu et al., 2005). Although the promoter region of TP53 does not contain a classic $\mathrm{CpG}$ island, the methylation of one or two CG sites may result in significant inhibitory effects in gene expression (Sidhu et al., 2005). As for the $\mathrm{LOH}$ in the region of the TP53 gene (17p13.1) or allelic imbalance (AI) as currently, the abnormality is detected in a majority of tumors leading to cancer progression and poor prognosis (Ellsworth et al., 2005; Frohling and Dohner, 2008; Lee et al., 2006; Tsuda, 2009; Willman and Hromas, 2010).

At present, it is not known which of these inactivation hits occurs first; however, the initial step by way of $\mathrm{LOH}$ is expected to create prerequisites for mutations in retained TP53 alleles through a significant increase in genomic instability caused by the dramatic reduction of p53 functionality. In contrast, point mutations and methylation do not always result in inactivation or alteration of the activity of the corresponding protein. Information concerning the simultaneous occurrence of $\mathrm{LOH}$ and mutations in the TP53 gene is well represented in association with rs1042522 alleles (Table 3). However, it was quite recently shown that rs17878362 and rs1625895 germline variations are also associated with TP53 somatic abnormalities in tumor cells (Denisov et al., 2011; Marcel et al., 2009), although the data are not numerous enough and require further confirmation. Several studies reported that LOH more often occurs at the $\mathrm{C}$ allele than at the G allele in tumor cells of rs1042522 heterozygous cancer patients. This phenomenon is typical for cancers of the breast (Bonafe et al., 2003; Denisov et al., 2009; Denisov et al., 2011; Wegman et al., 2009), lung (Nelson et al., 2005; Papadakis et al., 2002), head and neck (Marin et al., 2000; Mitra et al., 2007), colon and rectum (Schneider-Stock et al., 2004a), renal pelvis, ureter and bladder (Furihata et al., 2002), oral cavity (Hsieh et al., 2005), vulva (Brooks et al., 2000; Marin et al., 2000), liver (Anzola et al., 2003), skin (Marin et al., 2000; McGregor et al., 2002), esophagus (Kawaguchi et al., 2000), and cervix (Pegoraro et al., 2002). However, the early studies on renal, bladder and oral cancer models did not show any differences in the preference of $\mathrm{LOH}$ at the rs1042522 alleles (Oka et al., 1991; Tandle et al., 2001). An interesting situation is that two reports involving ovary cancer have demonstrated contradictory results concerning preferential loss of the rs1042522 alleles in tumor (Buller et al., 1997; Wang et al., 2004); however, in a study by Wang et al. (Wang et al., 2004), the differences did not reach statistical significance. In a majority of cancers with a loss of the C allele, TP53 gene mutations are significantly more frequent displayed in the retained $G$ variant. Interestingly, persons with the GG and GC genotype in blood also have an increased frequency of TP53 somatic mutations (Table 3). 


\begin{tabular}{|c|c|c|c|c|c|}
\hline \multirow[t]{2}{*}{ Cancers } & \multicolumn{2}{|c|}{$\begin{array}{l}\text { Preferential } \\
\text { loss }\end{array}$} & \multicolumn{2}{|c|}{$\begin{array}{c}\text { Preferential } \\
\text { mutation }\end{array}$} & \multirow[t]{2}{*}{ Ref. } \\
\hline & G & $\mathrm{C}$ & $\mathrm{G}$ & $\mathrm{C}$ & \\
\hline \multirow{5}{*}{ Breast } & yes & no & no & no & (Kyndi et al., 2006) \\
\hline & no & yes & - & - & (Bonafe et al., 2003) \\
\hline & - & - & yes & no & (Langerod et al., 2002) \\
\hline & no & yes & yes & no & (Wegman et al., 2009) \\
\hline & no & yes & yes & no & $\begin{array}{l}\text { (Denisov et al., 2009; } \\
\text { Denisov et al., 2011) }\end{array}$ \\
\hline \multirow{2}{*}{ Head and neck } & no & yes & yes & no & (Mitra et al., 2007) \\
\hline & no & yes & yes & no & (Marin et al., 2000) \\
\hline \multirow{2}{*}{$\begin{array}{l}\text { Renal pelvis, } \\
\text { ureter and bladder }\end{array}$} & no & no & - & - & (Oka et al., 1991) \\
\hline & no & yes & yes & no & (Furihata et al., 2002) \\
\hline \multirow{2}{*}{ Oral cavity } & no & yes ${ }^{\dagger}$ & yes & no & (Hsieh et al., 2005) \\
\hline & no & no & - & - & (Tandle et al., 2001) \\
\hline \multirow{2}{*}{ Colon and rectum } & no & yes & yes & no & (Schneider-Stock et al., 2004a) \\
\hline & - & - & yes & no & (Godai et al., 2009) \\
\hline Stomach & - & - & no & no & (Belyavskaya et al., 2006) \\
\hline \multirow{2}{*}{ Vulva } & no & yes & yes & no & (Brooks et al., 2000) \\
\hline & no & yes & yes & no & \multirow{2}{*}{ (Marin et al., 2000) } \\
\hline \multirow{3}{*}{ Skin } & no & yes & yes & no & \\
\hline & - & - & no & yes & (Almquist et al., 2011) \\
\hline & no & yes & no & no & (McGregor et al., 2002) \\
\hline $\begin{array}{l}\text { Liver (hepatitis C } \\
\text { virus) }\end{array}$ & no & yes & - & - & (Anzola et al., 2003) \\
\hline Esophagus (HPV) & no & yes & - & - & (Kawaguchi et al., 2000) \\
\hline Cervix (HPV) & no & yes & - & - & (Pegoraro et al., 2002) \\
\hline Ovary & no & yes & no & yes & (Buller et al., 1997) \\
\hline $\begin{array}{l}\text { - advanced } \\
\text { cancer }\end{array}$ & yes & no & no & yes & (Wang et al., 2004) \\
\hline \multicolumn{6}{|l|}{ Lung } \\
\hline \multirow{3}{*}{$\begin{array}{l}\text { - non-small cell } \\
\text { cancer }\end{array}$} & - & - & no & yes & $\begin{array}{l}\text { (Hu et al., 2005; Mechanic et al., } \\
\text { 2005; Szymanowska et al., } \\
\text { 2006) }\end{array}$ \\
\hline & - & - & yes & no & (Lind et al., 2007) \\
\hline & no & yes & yes & no & (Nelson et al., 2005) \\
\hline $\begin{array}{l}\text { - advanced } \\
\text { cancer }\end{array}$ & no & yes & - & - & (Papadakis et al., 2002) \\
\hline $\begin{array}{l}\text { Total group of } \\
\text { human cancers at } \\
\text { the background of } \\
\text { radiation }\end{array}$ & no & yes & - & - & [own unpublished data] \\
\hline
\end{tabular}

†C allele is preferentially lost in oral squamous cell carcinomas associated with cigarette smoking and areca quid chewing, while the frequency of $G$ allele loss is increased with alcohol drinking.

Table 3. The preferential loss and mutation of TP53 rs1042522 alleles in human cancer. 
Selective loss of the rs1042522 C allele and retention and mutation of the G variant seems to be a unique phenomenon, of which the molecular mechanism, point of origin and biological significance remain unclear. As opposed to hereditary cancer, the origin of which occurs in Knudson's "two-hit" model, in sporadic tumors, the question of whether the mutation or $\mathrm{LOH}$ arises first is not resolved, likely due to the high variability of inactivation modes among target (tumor suppressor) genes in cancer development (Thiagalingam et al., 2002; Wilentz et al., 2001). Thus, one may suppose that the $\mathrm{LOH}$ and mutations arise in any alleles and in any order but not simultaneously in the two allelic variants because the chances of this "scenario" are very low. Accordingly, in TP53 rs1042522 heterozygous carriers, the following groups of cells are theoretically possible: with $\mathrm{LOH}$ at both the $\mathrm{C}$ and $\mathrm{G}$ alleles and mutations in both the $\mathrm{C}$ and $\mathrm{G}$ alleles (Fig. 1). It is most likely that any variations from monoallelic inactivation hits may provoke neoplastic transformation because a $50 \%$ reduction in TP53 gene dosage, protein expression and activity is sufficient to promote tumorigenesis (Donehower and Lozano, 2009); however, loss of the chromosome region underlying $\mathrm{LOH}$ is always more dramatic than point mutation. The selective advantage will be displayed for the two groups of cells lacking the $C$ allele and having a mutation in the $G$ variant because of the uncontrolled proliferation caused by the withdrawal of cell cycle checking and the high survival capacity in hypoxia and conditions of chemotherapy provoked by the preferential activation of hypoxia and multidrug resistance genes by p53Arg and inactivation of p73 protein, an important determinant of cellular sensitivity to anticancer agents (Bergamaschi et al., 2003; Sansone et al., 2007; Siddique and Sabapathy, 2006; Vannini et al., 2008). The dramatically increased genomic instability in these cells will most likely result in the second inactivation hit by mutation of the retained $G$ allele in one clone and loss of the $\mathrm{C}$ variant in the other. Thus, any of these variants will lead to formation of a cell clone lacking the $C$ allele and having the mutated $G$ variant, the presence of which has been reported in a majority of human cancers (see above). As opposed to single monoallelic inactivation sufficient for tumorigenesis, biallelic switching of p53 activity may accelerate tumors to invade and metastasize. Taken together, the "two-hit" model of TP53 somatic abnormalities was suggested to explain the regular occurrence of loss of the rs1042522 C allele and mutation of the G variant in human tumors.

The biological value of TP53 somatic abnormalities in the rs1042522 polymorphic region is well investigated in relation to tumor onset and progression. Nonetheless, there are difficulties in determining the specific interrelationship between certain rs1042522 inactivation hits and tumor development, perhaps due to tissue-specific manifestation of TP53 allelic variants (Azzam et al., 2011). In particular, the positive contribution of loss of the $C$ allele to short disease-free and overall survival, as well as tumor spreading, has been established in breast and colorectal cancers (Bonafe et al., 2003; Schneider-Stock et al., 2004a). Interestingly, inactivation of the $\mathrm{C}$ allele, already having mutations, has been associated with short survival and a worse outcome in patients with lung, ovarian and colorectal neoplasias (Godai et al., 2009; Nelson et al., 2005; Wang et al., 2004). In contrast, patients lacking the G variant in breast tumors possessed early tumor onset and more recurrence and short disease-free survival (Kyndi et al., 2006; Wegman et al., 2009). In addition, it should be pointed out that preferential loss of the $\mathrm{C}$ allele in human tumors may imply a protective effect of this variant regarding cancer development (Denisov et al., 2010; Denisov et al., 2011); however, the current disagreements between meta-analyses (Table 2) and studies reporting rs1042522 allelic loss in tumors (Table 3) allow us to consider this statement as not quite truthful. Likely, further studies are needed to clarify the above-mentioned hypothesis. 


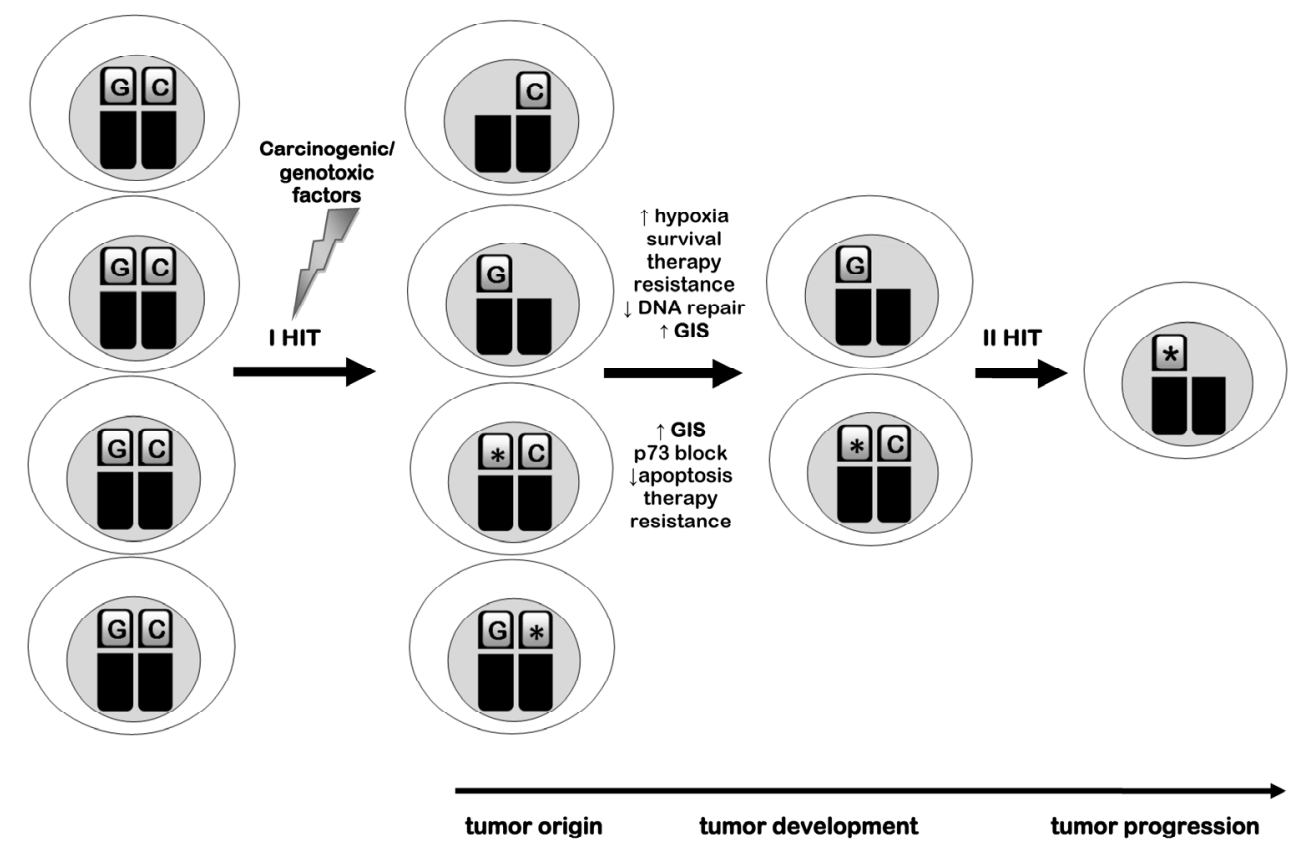

Fig. 1. The "two-hit" model of regular occurrence of TP53 somatic abnormalities depending on the TP53 rs1042522 polymorphism and environmental exposure. This model describes rs1042522-specific origin of TP53 somatic aberrations in cancer tumors. At the first stage, $\mathrm{LOH}$ (indicated as a loss of chromosome arm) and/or mutation (indicated as asterisk on the chromosome arm) arise in any rs1042522 allele and in any order resulting in neoplastic transformation. From all tumor clones, only two ones with loss of the $\mathrm{C}$ allele and mutation in the $G$ variant will have selective advantage via high survival capacity in hypoxia and therapy conditions, low ability to DNA repair and apoptosis. The dramatically increased genomic instability (GIS) in these cells will cause second inactivation forming the predominant tumor clone with loss of the $\mathrm{C}$ allele and mutation in the retained $\mathrm{G}$ variant. It is most likely that complete inactivation of p53 will impart invasive and/or metastatic potential to these cells.

In summary, the cancer predisposing effect of the TP53 rs1042522 polymorphism through environment-induced regular occurrence of TP53 somatic abnormalities has been reviewed in the present study. The "two-hit" model was suggested to explain the universal phenomenon for a majority of human tumors, consisting of a preferential loss of the $\mathrm{C}$ allele and mutation of the $G$ variant. As reviewed herein, functional differentiation between rs1042522 allelic variants and its tissue specificity underlie selective pressure to maintain cells in which the $C$ allele is lost and the $G$ allele is mutated. Moreover, the inactivation of both the $\mathrm{C}$ and $\mathrm{G}$ allelic variants, resulting in a dramatic reduction in p53 functionality, may serve as an important background for tumorigenesis, as explained by the results of a study series on the association of TP53 abnormalities in the rs1042522 polymorphic region with 
tumor onset and aggressiveness (Bonafe et al., 2003; Godai et al., 2009; Kyndi et al., 2006; Nelson et al., 2005; Schneider-Stock et al., 2004a; Wang et al., 2004; Wegman et al., 2009).

\subsection{TP53 polymorphisms: The cancer predisposing effect and aging}

p53 is emerging as an important player in the regulation of senescence and longevity with pronounced antagonistic pleiotropy (Campisi, 2005; Donehower, 2006; Vigneron and Vousden, 2010). By suppressing cancers early in life, p53 is clearly a longevity assurance gene. However, there is some evidence that p53 might accelerate aging and reduce longevity late in life (Donehower, 2006). Results have shown that the genotype distribution of TP53 polymorphisms, mainly the rs1042522 germline variation, in both healthy persons and cancer patients, is also consistent with antagonistic pleiotropy. As early as 1999, Bonafe et al. (Bonafe et al., 1999) demonstrated a slightly increased percentage of rs1042522 C carriers among Italian centenarians. Later, this research team reported that the presence of only major genotypes for rs1042522, rs17878362, and rs1625895, absence of the GSTT1 deletion, and the simultaneous occurrence of the TP53 genotypes with minor alleles and the GSTT1 deletion, were much more frequent in young subjects than in centenarians (Gaspari et al., 2003). However, our data did not confirm this fact, likely due to the small study sample (Belyavskaya et al., 2005). Based on the observations, it is most likely that the reason for disagreement can be explained by the different genetic backgrounds modifying the agespecific functionality of TP53 polymorphisms (Belyavskaya et al., 2005). With respect to cancer, an age-specific dependence of cancer risk has been reported for TP53 polymorphisms (Cherdyntseva et al., 2010; Chung et al., 2010; Gervas et al., 2007; Perel'muter et al., 2008). In this aspect, it is of note that some contradictions in the abovementioned meta-analyses could be due to age-related effects of TP53 germline variations. For example, breast cancer is one of a few diseases for which TP53 rs1042522 polymorphism raises many questions (He et al., 2011; Hu et al., 2010b; Lu et al., 2011b; Ma et al., 2011; Peng et al., 2011; Sergentanis and Economopoulos, 2010b; The Breast Cancer Association Consortium, 2006; Zhang et al., 2010b; Zhuo et al., 2009a). According to our data, the C allele contributes to high breast cancer risk in the premenopausal period (Cherdyntseva et al., 2011), whereas a combination of rs1042522, rs17878362, and rs1625895 major genotypes often occurs in postmenopausal BC (Perel'muter et al., 2008). Therefore, a more accurate meta-analysis that takes into account age specificity is required to clarify the associations between rs1042522 and breast cancer risk. Interestingly, an age-associated change in the TP53 genotype distribution was also observed for lung cancer: the elderly (60-79 yr) affected subjects were characterized by an increased frequency of TP53 major genotypes, whereas a high proportion of heterozygous genotype combinations was frequently detected in mature (40-59 yr) patients (Cherdyntseva et al., 2010; Gervas et al., 2007). These data not only agreed with recent meta-analyses (Dai et al., 2009; Francisco et al., 2010; Li et al., 2009; Yan et al., 2009) but also suggest that age might be an important modifier of the association between TP53 rs1042522 polymorphism and lung cancer risk. With regard to rs17878362 and rs1625895 germline variations, the alteration in frequency of their genotypes is most likely linked to the regulation of TP53 gene dosage particularly that which results in an increase in expression of the rs1042522 G allele, as already mentioned previously. Curiously enough, a high percentage of rs1042522 GG genotype was displayed in elderly patients with both breast and lung cancer. It is possible that apoptosis preferentially activated by p53Arg protein can lead to tissue atrophy, organ degeneration and cancer-related aging phenotypes (Campisi, 2005; Rodier et al., 2007). Moreover, it is known that the effect of TP53 rs1042522 
polymorphism becomes evident as the age of individuals increases (Bonafe et al., 2004; Salvioli et al., 2005). In particular, cells isolated from centenarians and sexagenarians, GG carriers, undergo oxidative stress-induced apoptosis to a higher extent than cells obtained from C carriers (Bonafe et al., 2004). Additionally, individuals that live a long time with the $\mathrm{C}$ allele display slower cell cycle kinetics and an increased propensity to undergo cell senescence than age-matched persons not expressing the C variant (Salvioli et al., 2005). These findings result from the preferential induction of p21, cyclin-dependent kinase inhibitor 1, and, likely, age-dependent activation of PAI-1, plasminogen activator inhibitor 1, by p53Pro protein (Salvioli et al., 2005; Testa et al., 2009).

Notwithstanding the age-specific effect of TP53 polymorphisms on cancer risk, interesting findings concerning their influence on longevity have been provided by Van Heemst et al. (van Heemst et al., 2005). Elderly patients, carriers of the CC genotype, display a $41 \%$ increased survival despite a 2.54-fold high cancer mortality. Interestingly, some have suggested that the increased longevity of individuals with the CC genotype may be due to a generally increased robustness after a diagnosis of cancer or other life-threatening diseases, perhaps via an age-dependent capability of p53Pro to stimulate the expression of PAI-1 (Bojesen and Nordestgaard, 2008; Orsted et al., 2007; Testa et al., 2009).

p53 is a central node in the molecular network of safeguarding the integrity of the genome. p53 activation can immediately result in alterations in the expression of more than a thousand genes (Kannan et al., 2011). However, the fate of p53 is also under the rigorous control of other molecular players. Quite recently, based on the results of an association study and epistatic interaction analysis, the age- and estrogen receptor-specific interplay between TP53 and FGFR2 has been demonstrated in breast cancer (Cherdyntseva et al., 2011). It was found that combinations of FGFR2 rs1219648 minor and TP53 rs1042522, rs17878362, and rs1625895 major genotypes were associated with a high risk of BC, particularly in the postmenopausal period. In contrast, combinations of the FGFR2 and TP53 major genotypes had a protective effect against BC, especially in premenopausal women. Of note, all observations were ER-dependent. A possible explanation arises from evidence that FGFR2, upregulated by estrogens through the rs1219648 ( $\mathrm{G}$ allele)-formed estrogen receptor site, may result in p53 inactivation via the induction of MDM2 ubiquitin ligase (Cherdyntseva et al., 2011). Importantly, the presence of the minor rs1219648 allele may lead to elevated FGFR2 expression in tumor cells by itself (Meyer et al., 2008). Another point of view is based on a molecular network consisting of the preferential activation of apoptosis and cancer-related aging phenotype by p53Arg protein and the further induction of FGFR2 expression leading to the transactivation of cancer genes and increased proliferation. The above-mentioned reasoning allows us once again to conclude that the p53-associated cellular defense system that controls cancer suppression directly depends on age-related features of the human organism, and this phenomenon should be taken into account in future association studies.

\subsection{TP53 polymorphisms: The cancer predisposing effect and ethnicity}

The TP53 polymorphism distribution dramatically changes across the globe (Beckman et al., 1994; Sjalander et al., 1996), indicating selective pressure to fix TP53 alleles in certain geographic areas. As noted in previous sections of this review, the functionally different p53 polymorphic proteins have the advantage of depending on specific environmental conditions (Hirshfield et al., 2010; Hu et al., 2011; Jeong et al., 2010). In addition, 
manifestation of the cancer predisposing effects of TP53 polymorphisms may also be altered between the different ethnic groups (Weston et al., 1997). In the literature, there is a significant amount of evidence that TP53 polymorphisms (rs1042522, rs17878362, and rs1625895) differently influence cancer risk depending on ethnic components. For instance, TP53 rs1042522 polymorphism has a protective value against breast cancer in inhabitants of the Mediterranean area (Hu et al., 2010b), but a predisposing effect in Indians (He et al., 2011). In addition, Sergentanis and Economopoulos (Sergentanis and Economopoulos, $2010 \mathrm{~b}$ ) showed an enhancement of the association between the $C$ allele and cancer, both breast cancer and lung cancer, with increasing latitude. Similar ethnicity-specific contribution of TP53 rs1042522 germline variation is also typical for other human cancers (Table 2) (Economopoulos et al., 2010; Gao et al., 2009; Jiang et al., 2010a; Li et al., 2010; Liu et al., 2011; Zhang et al., 2010a). Interestingly enough, the allelic expression of human genes, like allele frequency, was found to differ between ethnic groups (Spielman et al., 2007). Siddique et al. showed that the expression of TP53 rs1042522 alleles is selectively regulated in different ethnic populations: healthy Asian heterozygote individuals preferentially express the $\mathrm{C}$ allele, whereas Caucasians express the $\mathrm{G}$ allele. Conversely, approximately $75 \%$ of Chinese heterozygote patients with breast cancer predominantly express the G allele (Siddique et al., 2005). Although the potential reason for this phenomenon could be preferential loss of the $\mathrm{C}$ allele in breast tumors of heterozygous patients, as mentioned above, the data of Siddique et al. may indirectly confirm a predisposing role of the $\mathrm{G}$ allele in breast cancer development, as shown in some meta-analyses (He et al., 2011; Lu et al., 2011b; Sergentanis and Economopoulos, 2010b; Zhang et al., 2010b). In addition, our research team first showed the high risk potential of the $G$ allele and trend toward the protective value of the $\mathrm{C}$ variant in relation to breast cancer development in Mongolian ethnic groups (Tuvans, Altaians, Khakases, and Buryats) living in the Siberia region of Russia (Pisareva et al., in press). It is of note that our earlier data demonstrated significantly lower breast cancer incidence in these ethnic groups in comparison with Caucasians living in the same region (Pisareva et al., 2007). Moreover, it is known that Caucasians are approximately 2-fold more prone to breast cancer than Asians (Siddique et al., 2005). As evident from the above, there is a specific selective pressure against high breast cancer incidence in people of Asian ethnicity, and a possible explanation for this might be the functional impact of the TP53 rs1042522 polymorphism, of which the $\mathrm{C}$ allele is overrepresented in these populations. As indicated previously, the TP53 rs1042522 polymorphism has a significant effect on the origin of TP53 somatic abnormalities, especially mutations, and, thus, may predispose one to cancer. Racespecific differences in the frequency of TP53 alterations have been shown between colorectal patients of Afro-American and Caucasian origin, with the prevalence of mutations in the former, which were rs1042522 CC carriers. Surprisingly, the African American CC genotype was associated with a high risk of lymph node metastasis and increased mortality (Katkoori et al., 2009). Although the above evidence is small in number and needs further approval, calculation of the ethnic component is essential to perform accurate and qualitatively correct association studies.

In summary, a disparity between different ethnicities (races) in various cancer incidences and outcomes depends on genetic differences affecting the biology of malignancy. Moreover, recent evidence indicates ethnic differences in toxicity from certain anticancer treatments as well their effectiveness, which apparently contributes to survival (Mahdi et al., 2011; Soo et al., 2011). This might be explained by the diversity in genotype variants, gene 
expression levels and epigenetic alterations providing different race/ethnicity-specific functional pathways. p53 is a key player contributing to the defense against cancer and has been shown to be involved in tumor progression and the response to cytostatic drugs via the regulation of metabolism and repair of DNA damage induced by chemotherapy. Therefore, the analysis of TP53 rs1042522 polymorphism together with other deciding factors may help to understand racial differences in cancer aggressiveness and clinical outcomes, which could increase treatment efficacy.

\section{Conclusions}

p53 (TP53 gene) is a key tumor suppressor that balances the need for cell proliferation against the need for cancer suppression, thereby maintaining genomic integrity. Polymorphisms in the TP53 gene significantly modify p53 functionality, thereby affecting the mechanisms of cancer prevention. Despite the substantial progress in molecular genetics and the understanding of tumorigenesis mechanisms in recent years, the value of TP53 polymorphisms is not entirely clear in relation to a predisposition to or protection from cancer risk. In the present review, we focused on available information concerning the functional role of TP53 polymorphisms and data from consortium works and the latest meta-analyses demonstrating their effect on cancer risk. We supposed that the disagreements and ambiguities in these studies are linked to the changeable nature of TP53 polymorphism manifestation dependent on environmental exposure, mainly age features and ethnic components of the analyzed individuals. In our opinion, the possible variations of the impact of TP53 polymorphisms on cancer susceptibility, mainly for rs1042522, might be presented as a complex gene-environmental mechanism realized through a regular occurrence of TP53 somatic abnormalities and selective pressure against certain TP53 alleles. Overall, the environment-specific character of TP53 polymorphisms has been reviewed to demonstrate potential cancer risk-modifying factors, which should be taken into account to avoid unclear and ambiguous results in future association studies.

\section{References}

Almeida, L.O., Custodio, A.C., Pinto, G.R., Santos, M.J., Almeida, J.R., Clara, C.A., Rey, J.A. \& Casartelli, C. (2009). Polymorphisms and DNA methylation of gene TP53 associated with extra-axial brain tumors. Genet Mol Res, Vol.8, No.1, pp. 8-18, (February 2009), ISSN 1676-5680

Almquist, L.M., Karagas, M.R., Christensen, B.C., Welsh, M.M., Perry, A.E., Storm, C.A. \& Nelson, H.H. (2011). The role of TP53 and MDM2 polymorphisms in TP53 mutagenesis and risk of non-melanoma skin cancer. Carcinogenesis, Vol.32, No.3, pp. 327-330, (December 2010), ISSN 1460-2180

Amatya, V.J., Naumann, U., Weller, M. \& Ohgaki, H. (2005). TP53 promoter methylation in human gliomas. Acta Neuropathol, Vol.110, No.2, pp. 178-184, (Jule 2005), ISSN 00016322

Anzola, M., Cuevas, N., Lopez-Martinez, M., Saiz, A., Burgos, J.J. \& de Pancorbo, M.M. (2003). Frequent loss of p53 codon 72 Pro variant in hepatitis C virus-positive carriers with hepatocellular carcinoma. Cancer Lett, Vol.193, No.2, pp. 199-205, (April 2003), ISSN 0304-3835 
Azzam, G.A., Frank, A.K., Hollstein, M. \& Murphy, M.E. (2011). Tissue-specific apoptotic effects of the p53 codon 72 polymorphism in a mouse model. Cell Cycle, Vol.10, No.9, pp. 1352-1355, (May 2011), ISSN 1551-4005

Baker, S.J., Preisinger, A.C., Jessup, J.M., Paraskeva, C., Markowitz, S., Willson, J.K., Hamilton, S. \& Vogelstein, B. (1990). p53 gene mutations occur in combination with $17 \mathrm{p}$ allelic deletions as late events in colorectal tumorigenesis. Cancer Res, Vol.50, No.23, pp. 7717-7722, (December 1990), ISSN 0008-5472

Beckman, G., Birgander, R., Sjalander, A., Saha, N., Holmberg, P.A., Kivela, A. \& Beckman, L. (1994). Is p53 polymorphism maintained by natural selection? Hum Hered, Vol.44, No.5, pp. 266-270, (September 1994), ISSN 0001-5652

Belyavskaya, V.A., Smetannikova, N.A., Maksimov, V.N., Smetannikova, M.A., Bolotnova, T.V., Ustinov, S.N., Shabalin, A.V. \& Voevoda, M.I. (2005). The search for "Longevity" and "Non-longevity" genes: the role of polymorphism of some keys genes of immunological homeostasis in development of pathology reducing lifespan. Molecular Medicine (Russian), Vol.3, pp. 55-60

Belyavskaya, V.A., Vardosanidze, V.K., Smirnova, O.Y., Karakin, E.I., Savkin, I.V., Gervas, P.A., Cherdyntseva, N.V. \& Voevoda, M.I. (2006). Genetic status of p53 in stomach cancer: somatic mutations and polymorphism of codon 72. Bull Exp Biol Med, Vol.141, No.2, pp. 243-246, (September 2006), ISSN 0007-4888

Bendesky, A., Rosales, A., Salazar, A.M., Sordo, M., Peniche, J. \& Ostrosky-Wegman, P. (2007). p53 codon 72 polymorphism, DNA damage and repair, and risk of non-melanoma skin cancer. Mutat Res, Vol.619, No.1-2, pp. 38-44, (April 2007), ISSN 0027-5107

Bergamaschi, D., Gasco, M., Hiller, L., Sullivan, A., Syed, N., Trigiante, G., Yulug, I., Merlano, M., Numico, G., Comino, A., Attard, M., Reelfs, O., Gusterson, B., Bell, A.K., Heath, V., Tavassoli, M., Farrell, P.J., Smith, P., Lu, X. \& Crook, T. (2003). p53 polymorphism influences response in cancer chemotherapy via modulation of p73-dependent apoptosis. Cancer Cell, Vol.3, No.4, pp. 387-402, (May 2003), ISSN 1535-6108

Biros, E., Kohut, A., Biros, I., Kalina, I., Bogyiova, E. \& Stubna, J. (2002). A link between the p53 germ line polymorphisms and white blood cells apoptosis in lung cancer patients. Lung Cancer, Vol.35, No.3, pp. 231-235, (February 2002), ISSN 0169-5002

Bojesen, S.E. \& Nordestgaard, B.G. (2008). The common germline Arg72Pro polymorphism of p53 and increased longevity in humans. Cell Cycle, Vol.7, No.2, pp. 158-163, (February 2008), ISSN 1551-4005

Bonafe, M., Olivieri, F., Mari, D., Baggio, G., Mattace, R., Berardelli, M., Sansoni, P., De Benedictis, G., De Luca, M., March egiani, F., Cavallone, L., Cardelli, M., Giovagnetti, S., Ferrucci, L., Amadio, L., Lisa, R., Tucci, M.G., Troiano, L., Pini, G., Gueresi, P., Morellini, M., Sorbi, S., Passeri, G., Barbi, C., Valensin, S., Monti, D., Deiana, L., Pes, G.M., Carru, C. \& Franceschi, C. (1999). P53 codon 72 polymorphism and longevity: additional data on centenarians from continental Italy and Sardinia. Am J Hum Genet, Vol.65, No.6, pp. 1782-1785, (December 1999), ISSN 0002-9297

Bonafe, M., Salvioli, S., Barbi, C., Mishto, M., Trapassi, C., Gemelli, C., Storci, G., Olivieri, F., Monti, D. \& Franceschi, C. (2002). p53 codon 72 genotype affects apoptosis by cytosine arabinoside in blood leukocytes. Biochem Biophys Res Commun, Vol.299, No.4, pp. 539-541, (December 2002), ISSN 0006-291X 
Bonafe, M., Ceccarelli, C., Farabegoli, F., Santini, D., Taffurelli, M., Barbi, C., Marzi, E., Trapassi, C., Storci, G., Olivieri, F. \& Franceschi, C. (2003). Retention of the p53 codon 72 arginine allele is associated with a reduction of disease-free and overall survival in arginine/proline heterozygous breast cancer patients. Clin Cancer Res, Vol.9, No.13, pp. 4860-4864, (October 2003), ISSN 1078-0432

Bonafe, M., Salvioli, S., Barbi, C., Trapassi, C., Tocco, F., Storci, G., Invidia, L., Vannini, I., Rossi, M., Marzi, E., Mishto, M., Capri, M., Olivieri, F., Antonicelli, R., Memo, M., Uberti, D., Nacmias, B., Sorbi, S., Monti, D. \& Franceschi, C. (2004). The different apoptotic potential of the p53 codon 72 alleles increases with age and modulates in vivo ischaemia-induced cell death. Cell Death Differ, Vol.11, No.9, pp. 962-973, (May 2004), ISSN 1350-9047

Brooks, L.A., Tidy, J.A., Gusterson, B., Hiller, L., O'Nions, J., Gasco, M., Marin, M.C., Farrell, P.J., Kaelin, W.G., Jr. \& Crook, T. (2000). Preferential retention of codon 72 arginine p53 in squamous cell carcinomas of the vulva occurs in cancers positive and negative for human papillomavirus. Cancer Res, Vol.60, No.24, pp. 6875-6877, (December 2000), ISSN 0008-5472

Brosh, R. \& Rotter, V. (2009). When mutants gain new powers: news from the mutant p53 field. Nat Rev Cancer, Vol.9, No.10, pp. 701-713, (August 2009), ISSN 1474-1768

Buller, R.E., Sood, A., Fullenkamp, C., Sorosky, J., Powills, K. \& Anderson, B. (1997). The influence of the p53 codon 72 polymorphism on ovarian carcinogenesis and prognosis. Cancer Gene Ther, Vol.4, No.4, pp. 239-245, (Jule 1997), ISSN 0929-1903

Campisi, J. (2005). Senescent cells, tumor suppression, and organismal aging: good citizens, bad neighbors. Cell, Vol.120, No.4, pp. 513-522, (March 2005), ISSN 0092-8674

Chang, C.J., Chao, C.H., Xia, W., Yang, J.Y., Xiong, Y., Li, C.W., Yu, W.H., Rehman, S.K., Hsu, J.L., Lee, H.H., Liu, M., Chen, C.T., Yu, D. \& Hung, M.C. (2011). p53 regulates epithelial-mesenchymal transition and stem cell properties through modulating miRNAs. Nat Cell Biol, Vol.13, No.3, pp. 317-323, (February 2011), ISSN 1476-4679

Chen, X., Liu, F., Li, B., Wei, Y.G., Yan, L.N. \& Wen, T.F. (2011). p53 codon 72 polymorphism and liver cancer susceptibility: a meta-analysis of epidemiologic studies. World J Gastroenterol, Vol.17, No.9, pp. 1211-1218, (March 2011), ISSN 1007-9327

Cherdyntseva, N., Gervas, P., Litvyakov, N., Stakcheeva, M., Ponomaryeva, A., Dobrodeev, A., Denisov, E., Belyavskaya, V. \& Choinzonov, E. (2010). Age-related function of tumor suppressor gene TP53: contribution to cancer risk and progression. Exp Oncol, Vol.32, No.3, pp. 205-208, (September 2010), ISSN 1812-9269

Cherdyntseva, N.V., Denisov, E.V., Litviakov, N.V., Maksimov, V.N., Malinovskaya, E.A., Babyshkina, N.N., Slonimskaya, E.M., Voevoda, M.I. \& Choinzonov, E.L. (2011). Crosstalk between the FGFR2 and TP53 genes in breast cancer: data from an association study and epistatic interaction analysis. DNA Cell Biol (August 2011), DOI: 10.1089/dna.2011.1351, ISSN 1044-5498

Chumakov, P.M. (2007). Versatile functions of p53 protein in multicellular organisms. Biochemistry (Mosc), Vol.72, No.13, pp. 1399-1421, (February 2008), ISSN 0006-2979

Chung, W.H., Dao, R.L., Chen, L.K. \& Hung, S.I. (2010). The role of genetic variants in human longevity. Ageing Res Rev, Vol.9, Suppl.1, pp. S67-78, (August 2010), ISSN 1872-9649 
Dahabreh, I.J., Linardou, H., Bouzika, P., Varvarigou, V. \& Murray, S. (2010). TP53 Arg72Pro polymorphism and colorectal cancer risk: a systematic review and meta-analysis. Cancer Epidemiol Biomarkers Prev, Vol.19, No.7, pp. 1840-1847, (Jule 2010), ISSN 15387755

Dai, S., Mao, C., Jiang, L., Wang, G. \& Cheng, H. (2009). P53 polymorphism and lung cancer susceptibility: a pooled analysis of 32 case-control studies. Hum Genet, Vol.125, No.5-6, pp. 633-638, (April 2009), ISSN 1432-1203

De Bont, R. \& van Larebeke, N. (2004). Endogenous DNA damage in humans: a review of quantitative data. Mutagenesis, Vol.19, No.3, pp. 169-185, (May 2004), ISSN 0267-8357

Denisov, E.V., Cherdyntseva, N.V., Litvyakov, N.V., Slonimskaya, E.M., Malinovskaya, E.A., Voevoda, M.I., Belyavskaya, V.A. \& Stegniy, V.N. (2009). TP53 mutations and Arg72Pro polymorphism in breast cancers. Cancer Genet Cytogenet, Vol.192, No.2. pp. 93-95, (Jule 2009), ISSN 1873-4456

Denisov, E.V., Litviakov, N.V., Goncharik, O.O., Karpov, A.B., Takhauov, R.M. \& Cherdyntseva, N.V. (2010). Genetic testing of cancer predisposition and progression: analysis of gene variations in tumor is required, Proceedings of 35 th ESMO Congress, pp. viii348-viii349, Milan, Italy, October 8-12, 2010.

Denisov, E.V., Sukhanovskaya, T.V., Dultseva, T.S., Malinovskaya, E.A., Litviakov, N.V., Slonimskaya, E.M., Choinzonov, E.L. \& Cherdyntseva, N.V. (2011). Coordination of TP53 abnormalities in breast cancer: data from analysis of TP53 polymorphisms, loss of heterozygosity, methylation and mutations.Genet Test Mol Biomarkers (August 2011), DOI: 10.1089/gtmb.2011.0038, ISSN 1945-0257

Donehower, L. (2006). p53, longevity assurance and longevity suppression. Drug Discovery Today: Disease Mechanisms, Vol.3, No.1, pp. 33-39, (Spring 2006)

Donehower, L.A. \& Lozano, G. (2009). 20 years studying p53 functions in genetically engineered mice. Nat Rev Cancer, Vol.9, No.11, pp. 831-841, (September 2009), ISSN 1474-1768

Dumont, P., Leu, J.I., Della Pietra, A.C., 3rd, George, D.L. \& Murphy, M. (2003). The codon 72 polymorphic variants of p53 have markedly different apoptotic potential. Nat Genet, Vol.33, No.3, pp. 357-365, (February 2003), ISSN 1061-4036

Economopoulos, K.P. \& Sergentanis, T.N. (2010). Methodological remarks concerning the recent meta-analysis on $\mathrm{p} 53$ codon 72 polymorphism and colorectal cancer risk. Eur J Surg Oncol, Vol.36, No.12, pp. 1225-1226; author reply 1227-1228, (October 2010), ISSN 1532-2157

Economopoulos, K.P., Sergentanis, T.N., Zagouri, F. \& Zografos, G.C. (2010). Association between p53 Arg72Pro polymorphism and colorectal cancer risk: a meta-analysis. Onkologie, Vol.33, No.12, pp. 666-674, (December 2010), ISSN 1423-0240

Ellsworth, R.E., Ellsworth, D.L., Neatrour, D.M., Deyarmin, B., Lubert, S.M., Sarachine, M.J., Brown, P., Hooke, J.A. \& Shriver, C.D. (2005). Allelic imbalance in primary breast carcinomas and metastatic tumors of the axillary lymph nodes. Mol Cancer Res, Vol.3, No.2, pp. 71-77, (March 2005), ISSN 1541-7786

Feng, Z., Zhang, C., Kang, H.J., Sun, Y., Wang, H., Naqvi, A., Frank, A.K., Rosenwaks, Z., Murphy, M.E., Levine, A.J. \& Hu, W. (2011). Regulation of female reproduction by p53 and its family members. FASEB J, Vol.25, No.7, pp. 2245-2255, (March 2011), ISSN 1530-6860 
Francisco, G., Menezes, P.R., Eluf-Neto, J. \& Chammas, R. (2010). Arg72Pro TP53 polymorphism and cancer susceptibility: A comprehensive meta-analysis of 302 case-control studies. Int J Cancer, Vol.129, No.4, pp. 920-930, (August 2010), ISSN 1097-0215

Frank, A.K., Leu, J.I., Zhou, Y., Devarajan, K., Nedelko, T., Klein-Szanto, A., Hollstein, M. \& Murphy, M.E. (2011). The codon 72 polymorphism of p53 regulates interaction with NF- $\{$ kappa $\} \mathrm{b}$ and transactivation of genes involved in immunity and inflammation. Mol Cell Biol, Vol.31, No.6, pp. 1201-1213, (January 2011), ISSN 1098-5549

Frohling, S. \& Dohner, H. (2008). Chromosomal abnormalities in cancer. N Engl J Med, Vol.359, No.7, pp. 722-734, (August 2008), ISSN 1533-4406

Furihata, M., Takeuchi, T., Matsumoto, M., Kurabayashi, A., Ohtsuki, Y., Terao, N., Kuwahara, M. \& Shuin, T. (2002). p53 mutation arising in Arg72 allele in the tumorigenesis and development of carcinoma of the urinary tract. Clin Cancer Res, Vol.8, No.5, pp. 1192-1195, (May 2002), ISSN 1078-0432

Gao, L., Nieters, A. \& Brenner, H. (2009). Cell proliferation-related genetic polymorphisms and gastric cancer risk: systematic review and meta-analysis. Eur J Hum Genet, Vol.17, No.12, pp. 1658-1667, (June 2009), ISSN 1476-5438

Gaspari, L., Pedotti, P., Bonafe, M., Franceschi, C., Marinelli, D., Mari, D., Garte, S. \& Taioli, E. (2003). Metabolic gene polymorphisms and p53 mutations in healthy centenarians and younger controls. Biomarkers, Vol.8, No.6, pp. 522-528, (June 2004), ISSN 1354-750X

Gemignani, F., Moreno, V., Landi, S., Moullan, N., Chabrier, A., Gutierrez-Enriquez, S., Hall, J., Guino, E., Peinado, M.A., Capella, G. \& Canzian, F. (2004). A TP53 polymorphism is associated with increased risk of colorectal cancer and with reduced levels of TP53 mRNA. Oncogene, Vol.23, No.10, pp. 1954-1956, (December 2003), ISSN 0950-9232

Gervas, P.A., Cherdyntseva, N.V., Belyavskaya, V.A., Vasileva, M.V., Dobrodeev, A.Y., Rudyk, Y.N., Miller, S.V., Tuzikov, S.A. \& Voevoda, M.I. (2007). Polymorphism of p53 gene-oncosupressor: age-specific features in the risk of lung cancer development. Siberian Journal of Oncology (Russian), Vol.2, No.22, pp. 49-54

Godai, T.I., Suda, T., Sugano, N., Tsuchida, K., Shiozawa, M., Sekiguchi, H., Sekiyama, A., Yoshihara, M., Matsukuma, S., Sakuma, Y., Tsuchiya, E., Kameda, Y., Akaike, M. \& Miyagi, Y. (2009). Identification of colorectal cancer patients with tumors carrying the TP53 mutation on the codon 72 proline allele that benefited most from 5fluorouracil (5-FU) based postoperative chemotherapy. BMC Cancer, Vol.9, pp. 420, (December 2009), ISSN 1471-2407

Green, D.R. \& Kroemer, G. (2009). Cytoplasmic functions of the tumour suppressor p53. Nature, Vol.458, No.7242, pp. 1127-1130, (May 2009), ISSN 1476-4687

Hanahan, D. \& Weinberg, R.A. (2011). Hallmarks of cancer: the next generation. Cell, Vol.144, No.5, pp. 646-674, (March 2011), ISSN 1097-4172

Harris, N., Brill, E., Shohat, O., Prokocimer, M., Wolf, D., Arai, N. \& Rotter, V. (1986). Molecular basis for heterogeneity of the human p53 protein. Mol Cell Biol, Vol.6, No.12, pp. 4650-4656, (December 1986), ISSN 0270-7306 
He, X.F., Su, J., Zhang, Y., Huang, X., Liu, Y., Ding, D.P., Wang, W. \& Arparkorn, K. (2011). Association between the p53 polymorphisms and breast cancer risk: meta-analysis based on case-control study. Breast Cancer Res Treat, (May 2011), DOI: 10.1007/s10549-011-1583-2, ISSN 1573-7217

Hirshfield, K.M., Rebbeck, T.R. \& Levine, A.J. (2010). Germline mutations and polymorphisms in the origins of cancers in women. J Oncol, Vol.2010, pp. 297671, (January 2010), ISSN 1687-8469

Hrstka, R., Coates, P.J. \& Vojtesek, B. (2009). Polymorphisms in p53 and the p53 pathway: roles in cancer susceptibility and response to treatment. J Cell Mol Med, Vol.13, No.3, pp. 440-453, (April 2009), ISSN 1582-4934

Hsieh, L.L., Huang, T.H., Chen, I.H., Liao, C.T., Wang, H.M., Lai, C.H., Liou, S.H., Chang, J.T. \& Cheng, A.J. (2005). p53 polymorphisms associated with mutations in and loss of heterozygosity of the p53 gene in male oral squamous cell carcinomas in Taiwan. Br J Cancer, Vol.92, No.1, pp. 30-35, (December 2004), ISSN 0007-0920

Hsu, P.Y., Hsu, H.K., Singer, G.A., Yan, P.S., Rodriguez, B.A., Liu, J.C., Weng, Y.I., Deatherage, D.E., Chen, Z., Pereira, J.S., Lopez, R., Russo, J., Wang, Q., Lamartiniere, C.A., Nephew, K.P. \& Huang, T.H. (2010). Estrogen-mediated epigenetic repression of large chromosomal regions through DNA looping. Genome Res, Vol.20, No.6, pp. 733-744, (May 2010), ISSN 1549-5469

$\mathrm{Hu}, \mathrm{W} .$, Zheng, T. \& Wang, J. (2011). Regulation of fertility by the p53 family members. Genes \& Cancer, (April 2011), Vol.2, No.4, pp.420-430, ISSN 1947-6019

$\mathrm{Hu}$, Y., McDermott, M.P. \& Ahrendt, S.A. (2005). The p53 codon 72 proline allele is associated with p53 gene mutations in non-small cell lung cancer. Clin Cancer Res, Vol.11, No.7, pp. 2502-2509, (April 2005), ISSN 1078-0432

Hu, Z., Li, X., Qu, X., He, Y., Ring, B.Z., Song, E. \& Su, L. (2010a). Intron 316 bp duplication polymorphism of TP53 contributes to cancer susceptibility: a meta-analysis. Carcinogenesis, Vol.31, No.4, pp. 643-647, (January 2010), ISSN 1460-2180

Hu, Z., Li, X., Yuan, R., Ring, B.Z. \& Su, L. (2010b). Three common TP53 polymorphisms in susceptibility to breast cancer, evidence from meta-analysis. Breast Cancer Res Treat, Vol.120, No.3, pp. 705-714, (August 2009), ISSN 1573-7217

Jeong, B.S., Hu, W., Belyi, V., Rabadan, R. \& Levine, A.J. (2010). Differential levels of transcription of p53-regulated genes by the arginine/proline polymorphism: p53 with arginine at codon 72 favors apoptosis. FASEB J, Vol.24, No.5, pp. 1347-1353, (December 2009), ISSN 1530-6860

Jiang, D.K., Ren, W.H., Yao, L., Wang, W.Z., Peng, B. \& Yu, L. (2010a). Meta-analysis of association between TP53 Arg72Pro polymorphism and bladder cancer risk. Urology, Vol.76, No.3, pp. 761-767, (Jule 2010), ISSN 1527-9995

Jiang, D.K., Yao, L., Ren, W.H., Wang, W.Z., Peng, B. \& Yu, L. (2010b). TP53 Arg72Pro polymorphism and endometrial cancer risk: a meta-analysis. Med Oncol, (June 2010), DOI: 10.1007/s12032-010-9597-x, ISSN 1559-131X

Jiang, D.K., Wang, W.Z., Ren, W.H., Yao, L., Peng, B. \& Yu, L. (2011). TP53 Arg72Pro polymorphism and skin cancer risk: a meta-analysis. J Invest Dermatol, Vol.131, No.1, pp. 220-228, (September 2010), ISSN 1523-1747 
Kang, H.J., Feng, Z., Sun, Y., Atwal, G., Murphy, M.E., Rebbeck, T.R., Rosenwaks, Z., Levine, A.J. \& Hu, W. (2009). Single-nucleotide polymorphisms in the p53 pathway regulate fertility in humans. Proc Natl Acad Sci U S A, Vol.106, No.24, pp. 9761-9766, (May 2009), ISSN 1091-6490

Kang, J.H., Kim, S.J., Noh, D.Y., Park, I.A., Choe, K.J., Yoo, O.J. \& Kang, H.S. (2001). Methylation in the p53 promoter is a supplementary route to breast carcinogenesis: correlation between $\mathrm{CpG}$ methylation in the p53 promoter and the mutation of the p53 gene in the progression from ductal carcinoma in situ to invasive ductal carcinoma. Lab Invest, Vol.81, No.4, pp. 573-579, (April 2001), ISSN 0023-6837

Kannan, K., Rechavi, G. \& Givol, D. (2011). p53's Dilemma in Transcription: Analysis by Microarrays, In: p53, A. Ayed \& T.Hupp, (Ed.), 216, Springer-Verlag, ISBN 978-14419-8230-8, New-York, USA

Katkoori, V.R., Jia, X., Shanmugam, C., Wan, W., Meleth, S., Bumpers, H., Grizzle, W.E. \& Manne, U. (2009). Prognostic significance of p53 codon 72 polymorphism differs with race in colorectal adenocarcinoma. Clin Cancer Res, Vol.15, No.7, pp. 24062416, (April 2009), ISSN 1078-0432

Kawaguchi, H., Ohno, S., Araki, K., Miyazaki, M., Saeki, H., Watanabe, M., Tanaka, S. \& Sugimachi, K. (2000). p53 polymorphism in human papillomavirus-associated esophageal cancer. Cancer Res, Vol.60, No.11, pp. 2753-2755, (June 2000), ISSN 00085472

Kay, C., Jeyendran, R.S. \& Coulam, C.B. (2006). p53 tumour suppressor gene polymorphism is associated with recurrent implantation failure. Reprod Biomed Online, Vol.13, No.4, pp. 492-496, (September 2006), ISSN 1472-6483

Khlgatian, M.K., Hadshiew, I.M., Asawanonda, P., Yaar, M., Eller, M.S., Fujita, M., Norris, D.A. \& Gilchrest, B.A. (2002). Tyrosinase gene expression is regulated by p53. J Invest Dermatol, Vol.118, No.1, pp. 126-132, (February 2002), ISSN 0022-202X

Klug, S.J., Ressing, M., Koenig, J., Abba, M.C., Agorastos, T., Brenna, S.M., Ciotti, M., Das, B.R., Del Mistro, A., Dybikowska, A., Giuliano, A.R., Gudleviciene, Z., Gyllensten, U., Haws, A.L., Helland, A., Herrington, C.S., Hildesheim, A., Humbey, O., Jee, S.H., Kim, J.W., Madeleine, M.M., Menczer, J., Ngan, H.Y., Nishikawa, A., Niwa, Y., Pegoraro, R., Pillai, M.R., Ranzani, G., Rezza, G., Rosenthal, A.N., Roychoudhury, S., Saranath, D., Schmitt, V.M., Sengupta, S., Settheetham-Ishida, W., Shirasawa, H., Snijders, P.J., Stoler, M.H., Suarez-Rincon, A.E., Szarka, K., Tachezy, R., Ueda, M., van der Zee, A.G., von Knebel Doeberitz, M., Wu, M.T., Yamashita, T., Zehbe, I. \& Blettner, M. (2009). TP53 codon 72 polymorphism and cervical cancer: a pooled analysis of individual data from 49 studies. Lancet Oncol, Vol.10, No.8, pp. 772-784, (Jule 2009), ISSN 1474-5488

Knudson, A.G., Jr. (1971). Mutation and cancer: statistical study of retinoblastoma. Proc Natl Acad Sci U S A, Vol.68, No.4, pp. 820-823, (April 1971), ISSN 0027-8424

Kyndi, M., Alsner, J., Hansen, L.L., Sorensen, F.B. \& Overgaard, J. (2006). LOH rather than genotypes of TP53 codon 72 is associated with disease-free survival in primary breast cancer. Acta Oncol, Vol.45, No.5, pp. 602-609, (Jule 2006), ISSN 0284-186X 
Langerod, A., Bukholm, I.R., Bregard, A., Lonning, P.E., Andersen, T.I., Rognum, T.O., Meling, G.I., Lothe, R.A. \& Borresen-Dale, A.L. (2002). The TP53 codon 72 polymorphism May affect the function of TP53 mutations in breast carcinomas but not in colorectal carcinomas. Cancer Epidemiol Biomarkers Prev, Vol.11, No.12, pp. 1684-1688, (December 2002), ISSN 1055-9965

Lee, S.H., Kim, S.R., Park, C.H., Cho, S.J. \& Choi, Y.H. (2006). Loss of heterozygosity of chromosome 17p13 and p53 expression in invasive ductal carcinomas. J Breast Cancer, Vol.9, No.4, pp. 309-316, (November 2006)

Li, D.B., Wei, X., Jiang, L.H., Wang, Y. \& Xu, F. (2010). Meta-analysis of epidemiological studies of association of P53 codon 72 polymorphism with bladder cancer. Genet Mol Res, Vol.9, No.3, pp. 1599-1605, (August 2010), ISSN 1676-5680

Li, Y., Qiu, L.X., Shen, X.K., Lv, X.J., Qian, X.P. \& Song, Y. (2009). A meta-analysis of TP53 codon 72 polymorphism and lung cancer risk: evidence from 15,857 subjects. Lung Cancer, Vol.66, No.1, pp. 15-21, (January 2009), ISSN 1872-8332

Lind, H., Ekstrom, P.O., Ryberg, D., Skaug, V., Andreassen, T., Stangeland, L., Haugen, A. \& Zienolddiny, S. (2007). Frequency of TP53 mutations in relation to Arg72Pro genotypes in non small cell lung cancer. Cancer Epidemiol Biomarkers Prev, Vol.16, No.10, pp. 2077-2081, (October 2007), ISSN 1055-9965

Litviakov, N., Denisov, E., Takhauov, R., Karpov, A., Skobel'skaja, E., Vasil'eva, E., Goncharik, O., Ageeva, A., Mamonova, N. \& Mezheritskiy, S. (2010). Association between TP53 gene ARG72PRO polymorphism and chromosome aberrations in human cancers. Molecular Carcinogenesis, Vol.49, No.6, pp. 521-524, (June 2010), ISSN 1098-2744

Liu, L., Wang, K., Zhu, Z.M. \& Shao, J.H. (2011). Associations between P53 Arg72Pro and development of digestive tract cancers: a meta-analysis. Arch Med Res, Vol.42, No.1, pp. 60-69, (March 2011), ISSN 1873-5487

Lu, P.H., Chen, M.B., Wei, M.X., Jiang, Z.Y. \& Li, C. (2011a). A small number of subjects do not always indicate that they are minor variants data for inclusion in a pooled analysis. Breast Cancer Res Treat, Vol.126, No.1, pp. 249-252, (November 2010), ISSN 1573-7217

Lu, P.H., Tao, G.Q., Liu, X., Li, C. \& Wei, M.X. (2011b). No significant association results obtained from significant association evidence: the ongoing uncertainty of TP53 codon 72 polymorphism and breast cancer risk. Breast Cancer Res Treat, Vol.125, No.2, pp. 601-603, (October 2010), ISSN 1573-7217

Lu, P.H., Wei, M.X., Li, C., Shen, W. \& Chen, M.B. (2011c). Need for clarification of data in a recent meta-analysis about TP53 codon 72 polymorphism and cancer susceptibility. Carcinogenesis, Vol.32, No.3, pp. 443, (December 2010), ISSN 1460-2180

Ma, Y., Yang, J., Liu, Z., Zhang, P., Yang, Z., Wang, Y. \& Qin, H. (2011). No significant association between the TP53 codon 72 polymorphism and breast cancer risk: a meta-analysis of 21 studies involving 24,063 subjects. Breast Cancer Res Treat, Vol.125, No.1, pp. 201-205, (May 2010), ISSN 1573-7217

Mahdi, H., Kumar, S., Hanna, R.K., Munkarah, A.R., Lockhart, D., Morris, R.T., Tamimi, H., Swensen, R.E. \& Doherty, M. (2011). Disparities in treatment and survival between African American and White women with vaginal cancer. Gynecol Oncol, Vol.122, No.1, pp. 38-41, (April 2011), ISSN 1095-6859 
Marcel, V., Palmero, E.I., Falagan-Lotsch, P., Martel-Planche, G., Ashton-Prolla, P., Olivier, M., Brentani, R.R., Hainaut, P. \& Achatz, M.I. (2009). TP53 PIN3 and MDM2 SNP309 polymorphisms as genetic modifiers in the Li-Fraumeni syndrome: impact on age at first diagnosis. J Med Genet, Vol.46, No.11, pp. 766-772, (June 2009), ISSN 1468-6244

Marcel, V., Tran, P.L., Sagne, C., Martel-Planche, G., Vaslin, L., Teulade-Fichou, M.P., Hall, J., Mergny, J.L., Hainaut, P. \& Van Dyck, E. (2011). G-quadruplex structures in TP53 intron 3: role in alternative splicing and in production of p53 mRNA isoforms. Carcinogenesis, Vol.32, No.3, pp. 271-278, (November 2010), ISSN 1460-2180

Marin, M.C., Jost, C.A., Brooks, L.A., Irwin, M.S., O'Nions, J., Tidy, J.A., James, N., McGregor, J.M., Harwood, C.A., Yulug, I.G., Vousden, K.H., Allday, M.J., Gusterson, B., Ikawa, S., Hinds, P.W., Crook, T. \& Kaelin, W.G., Jr. (2000). A common polymorphism acts as an intragenic modifier of mutant p53 behaviour. Nat Genet, Vol.25, No.1, pp. 47-54, (May 2000), ISSN 1061-4036

Marshall, C.J. (1991). Tumor suppressor genes. Cell, Vol.64, No.2, pp. 313-326, (January 1991), ISSN 0092-8674

McCarthy, N. (2011). Tumour suppressors: Selective justice. Nat Rev Cancer, Vol.11, No.1, pp. 4, (January 2011), ISSN 1474-1768

McGregor, J.M., Harwood, C.A., Brooks, L., Fisher, S.A., Kelly, D.A., O'Nions, J., Young, A.R., Surentheran, T., Breuer, J., Millard, T.P., Lewis, C.M., Leigh, I.M., Storey, A. \& Crook, T. (2002). Relationship between p53 codon 72 polymorphism and susceptibility to sunburn and skin cancer. J Invest Dermatol, Vol.119, No.1, pp. 8490, (August 2002), ISSN 0022-202X

Mechanic, L.E., Marrogi, A.J., Welsh, J.A., Bowman, E.D., Khan, M.A., Enewold, L., Zheng, Y.L., Chanock, S., Shields, P.G. \& Harris, C.C. (2005). Polymorphisms in XPD and TP53 and mutation in human lung cancer. Carcinogenesis, Vol.26, No.3, pp. 597-604, (November 2004), ISSN 0143-3334

Meyer, K.B., Maia, A.T., O'Reilly, M., Teschendorff, A.E., Chin, S.F., Caldas, C. \& Ponder, B.A. (2008). Allele-specific up-regulation of FGFR2 increases susceptibility to breast cancer. PLoS Biol, Vol.6, No.5, pp. e108, (May 2008), ISSN 1545-7885

Mitra, S., Banerjee, S., Misra, C., Singh, R.K., Roy, A., Sengupta, A., Panda, C.K. \& Roychoudhury, S. (2007). Interplay between human papilloma virus infection and p53 gene alterations in head and neck squamous cell carcinoma of an Indian patient population. J Clin Pathol, Vol.60, No.9, pp. 1040-1047, (November 2006), ISSN 00219746

Mizuno, H., Spike, B.T., Wahl, G.M. \& Levine, A.J. (2010). Inactivation of p53 in breast cancers correlates with stem cell transcriptional signatures. Proc Natl Acad Sci U S A, Vol.107, No.52, pp. 22745-22750, (December 2010), ISSN 1091-6490

Muller, P.A., Vousden, K.H. \& Norman, J.C. (2011). p53 and its mutants in tumor cell migration and invasion. J Cell Biol, Vol.192, No.2, pp. 209-218, (January 2011), ISSN 1540-8140

Murase, D., Hachiya, A., Amano, Y., Ohuchi, A., Kitahara, T. \& Takema, Y. (2009). The essential role of p53 in hyperpigmentation of the skin via regulation of paracrine melanogenic cytokine receptor signaling. J Biol Chem, Vol.284, No.7, pp. 4343-4353, (December 2008), ISSN 0021-9258 
Naldi, M., Pistolozzi, M., Bertucci, C., De Simone, A., Altilia, S., Pierini, M., Franceschi, C., Salvioli, S. \& Andrisano, V. (2010). Structural characterization of p53 isoforms due to the polymorphism at codon 72 by mass spectrometry and circular dichroism. $J$ Pharm Biomed Anal, Vol.53, No.2, pp. 200-206, (April 2010), ISSN 1873-264X

Nelson, H.H., Wilkojmen, M., Marsit, C.J. \& Kelsey, K.T. (2005). TP53 mutation, allelism and survival in non-small cell lung cancer. Carcinogenesis, Vol.26, No.10, pp. 1770-1773, (May 2005), ISSN 0143-3334

Nigro, J.M., Baker, S.J., Preisinger, A.C., Jessup, J.M., Hostetter, R., Cleary, K., Bigner, S.H., Davidson, N., Baylin, S., Devilee, P. \& et al. (1989). Mutations in the p53 gene occur in diverse human tumour types. Nature, Vol.342, No.6250, pp. 705-708, (December 1989), ISSN 0028-0836

Nikbahkt Dastjerdi, M. (2011). TP53 codon 72 polymorphism and p53 protein expression in colorectal cancer specimens in isfahan. Acta Med Iran, Vol.49, No.2, pp. 71-77, (May 2011), ISSN 1735-9694

Nordgard, S.H., Alnaes, G.I., Hihn, B., Lingjaerde, O.C., Liestol, K., Tsalenko, A., Sorlie, T., Lonning, P.E., Borresen-Dale, A.L. \& Kristensen, V.N. (2008). Pathway based analysis of SNPs with relevance to 5-FU therapy: relation to intratumoral mRNA expression and survival. Int J Cancer, Vol.123, No.3, pp. 577-585, (May 2008), ISSN 1097-0215

Oka, K., Ishikawa, J., Bruner, J.M., Takahashi, R. \& Saya, H. (1991). Detection of loss of heterozygosity in the p53 gene in renal cell carcinoma and bladder cancer using the polymerase chain reaction. Mol Carcinog, Vol.4, No.1, pp. 10-13, (January 1991), ISSN 0899-1987

Olivier, M., Hollstein, M. \& Hainaut, P. (2010). TP53 mutations in human cancers: origins, consequences, and clinical use. Cold Spring Harb Perspect Biol, Vol.2, No.1, pp. a001008, (February 2010), ISSN 1943-0264

Olovnikov, I.A., Kravchenko, J.E. \& Chumakov, P.M. (2009). Homeostatic functions of the p53 tumor suppressor: regulation of energy metabolism and antioxidant defense. Semin Cancer Biol, Vol.19, No.1, pp. 32-41, (December 2008), ISSN 1096-3650

Oren, M. \& Rotter, V. (2010). Mutant p53 gain-of-function in cancer. Cold Spring Harb Perspect Biol, Vol.2, No.2, pp. a001107, (February 2010), ISSN 1943-0264

Orsted, D.D., Bojesen, S.E., Tybjaerg-Hansen, A. \& Nordestgaard, B.G. (2007). Tumor suppressor p53 Arg72Pro polymorphism and longevity, cancer survival, and risk of cancer in the general population. J Exp Med, Vol.204, No.6, pp. 1295-1301, (May 2007), ISSN 0022-1007

Ozeki, C., Sawai, Y., Shibata, T., Kohno, T., Okamoto, K., Yokota, J., Tashiro, F., Tanuma, S., Sakai, R., Kawase, T., Kitabayashi, I., Taya, Y. \& Ohki, R. (2011). Cancer Susceptibility Polymorphism of p53 at Codon 72 Affects Phosphorylation and Degradation of p53 Protein. J Biol Chem, Vol.286, No.20, pp. 18251-18260, (April 2011), ISSN 1083-351X

Papadakis, E.D., Soulitzis, N. \& Spandidos, D.A. (2002). Association of p53 codon 72 polymorphism with advanced lung cancer: the Arg allele is preferentially retained in tumours arising in Arg/Pro germline heterozygotes. Br J Cancer, Vol.87, No.9, pp. 1013-1018, (November 2002), ISSN 0007-0920 
Pegoraro, R.J., Rom, L., Lanning, P.A., Moodley, M., Naiker, S. \& Moodley, J. (2002). P53 codon 72 polymorphism and human papillomavirus type in relation to cervical cancer in South African women. Int J Gynecol Cancer, Vol.12, No.4, pp. 383-388, (Jule 2002), ISSN 1048-891X

Peng, S., Lu, B., Ruan, W., Zhu, Y., Sheng, H. \& Lai, M. (2011). Genetic polymorphisms and breast cancer risk: evidence from meta-analyses, pooled analyses, and genomewide association studies. Breast Cancer Res Treat, Vol.127, No.2, pp. 309-324, (March 2011), ISSN 1573-7217

Perel'muter, V.M., Zav'ialova, M.V., Vtorushin, S.V., Slonimskaia, E.M., Kritskaia, N.G., Garbukov, E., Litviakov, N.V., Stakheeva, M.N., Babyshkina, N.N., Malinovskaia, E.A., Denisov, E.V., Grigor'eva, E.S., Nazarenko, M.S., Sennikov, S.V., Goreva, E.P., Kozlov, V.A., Voevoda, M.I., Maksimov, V.N., Beliavskaia, V.A. \& Cherdyntseva, N.V. (2008). Genetic and clinical and pathological characteristics of breast cancer in premenopausal and postmenopausal women. Adv Gerontol (Russian), Vol.21, No.4, pp. 643-653, (January 2008), ISSN 1561-9125

Perez-Losada, J., Castellanos-Martin, A. \& Mao, J.H. (2011). Cancer evolution and individual susceptibility. Integr Biol (Camb), Vol.3, No.4, pp. 316-328, (January 2011), ISSN 1757-9708

Petitjean, A., Achatz, M., Borresen-Dale, A., Hainaut, P. \& Olivier, M. (2007a). TP53 mutations in human cancers: functional selection and impact on cancer prognosis and outcomes. Oncogene, Vol.26, No.15, pp. 2157-2165, (April 2007), ISSN 0950-9232

Petitjean, A., Mathe, E., Kato, S., Ishioka, C., Tavtigian, S.V., Hainaut, P. \& Olivier, M. (2007b). Impact of mutant p53 functional properties on TP53 mutation patterns and tumor phenotype: lessons from recent developments in the IARC TP53 database. Hum Mutat, Vol.28, No.6, pp. 622-629, (February 2007), ISSN 1098-1004

Pezeshki, A., Sari-Aslani, F., Ghaderi, A. \& Doroudchi, M. (2006). p53 codon 72 polymorphism in basal cell carcinoma of the skin. Pathol Oncol Res, Vol.12, No.1, pp. 29-33, (March 2006), ISSN 1219-4956

Pim, D. \& Banks, L. (2004). p53 polymorphic variants at codon 72 exert different effects on cell cycle progression. Int J Cancer, Vol.108, No.2, pp. 196-199, (November 2003), ISSN 0020-7136

Pisareva, L.F., Odintsova, I.N., Ivanov, P.M. \& Nikolaeva, T.I. (2007). The breast cancer incidence in aboriginal and alien population of Sakha Republic. Siberian Journal of Oncology (Russian), Vol.3, pp. 69-72

Pisareva, L.F., Odintsova, I.N., Ananina, O.A., Malinovskaia, E.A., Stukanov, S.L., Panferova, E.V., Shivit-ool, A.A., Choinzonov, E.L. \& Cherdyntseva, N.V. (in press). Breast cancer incidence in Caucasian and Mongolian populations living in Siberia and Far East region of Russian Federation. Zdravookhranenie Rossiiskoi Federatsii (Russian)

Qiu, Y.L., Wang, W., Wang, T., Liu, J., Sun, P., Qian, J., Jin, L. \& Xia, Z.L. (2008). Genetic polymorphisms, messenger RNA expression of p53, p21, and CCND1, and possible links with chromosomal aberrations in Chinese vinyl chloride-exposed workers. Cancer Epidemiol Biomarkers Prev, Vol.17, No.10, pp. 2578-2584, (October 2008), ISSN 1055-9965 
Ribeiro, J.C., Barnetson, A.R., Fisher, R.J., Mameghan, H. \& Russell, P.J. (1997). Relationship between radiation response and p53 status in human bladder cancer cells. Int $J$ Radiat Biol, Vol.72, No.1, pp. 11-20, (Jule 1997), ISSN 0955-3002

Rivlin, N., Brosh, R., Oren, M. \& Rotter, V. (2011). Mutations in the p53 Tumor Suppressor Gene: Important Milestones at the Various Steps of Tumorigenesis. Genes \& Cancer, (April 2011), Vol.2, No.4, pp.466-474, ISSN 1947-6027

Rodier, F., Campisi, J. \& Bhaumik, D. (2007). Two faces of p53: aging and tumor suppression. Nucleic Acids Res, Vol.35, No.22, pp. 7475-7484, (October 2007), ISSN 1362-4962

Salvioli, S., Bonafe, M., Barbi, C., Storci, G., Trapassi, C., Tocco, F., Gravina, S., Rossi, M., Tiberi, L., Mondello, C., Monti, D. \& Franceschi, C. (2005). p53 codon 72 alleles influence the response to anticancer drugs in cells from aged people by regulating the cell cycle inhibitor p21WAF1. Cell Cycle, Vol.4, No.9, pp. 1264-1271, (August 2005), ISSN 1551-4005

Sansone, P., Storci, G., Pandolfi, S., Montanaro, L., Chieco, P. \& Bonafe, M. (2007). The p53 codon 72 proline allele is endowed with enhanced cell-death inducing potential in cancer cells exposed to hypoxia. Br J Cancer, Vol.96, No.8, pp. 1302-1308, (April 2007), ISSN 0007-0920

Sarig, R., Rivlin, N., Brosh, R., Bornstein, C., Kamer, I., Ezra, O., Molchadsky, A., Goldfinger, N., Brenner, O. \& Rotter, V. (2010). Mutant p53 facilitates somatic cell reprogramming and augments the malignant potential of reprogrammed cells. $J$ Exp Med, Vol.207, No.10, pp. 2127-2140, (August 2010), ISSN 1540-9538

Schildkraut, J.M., Goode, E.L., Clyde, M.A., Iversen, E.S., Moorman, P.G., Berchuck, A., Marks, J.R., Lissowska, J., Brinton, L., Peplonska, B., Cunningham, J.M., Vierkant, R.A., Rider, D.N., Chenevix-Trench, G., Webb, P.M., Beesley, J., Chen, X., Phelan, C., Sutphen, R., Sellers, T.A., Pearce, L., Wu, A.H., Van Den Berg, D., Conti, D., Elund, C.K., Anderson, R., Goodman, M.T., Lurie, G., Carney, M.E., Thompson, P.J., Gayther, S.A., Ramus, S.J., Jacobs, I., Kruger Kjaer, S., Hogdall, E., Blaakaer, J., Hogdall, C., Easton, D.F., Song, H., Pharoah, P.D., Whittemore, A.S., McGuire, V., Quaye, L., Anton-Culver, H., Ziogas, A., Terry, K.L., Cramer, D.W., Hankinson, S.E., Tworoger, S.S., Calingaert, B., Chanock, S., Sherman, M. \& Garcia-Closas, M. (2009). Single nucleotide polymorphisms in the TP53 region and susceptibility to invasive epithelial ovarian cancer. Cancer Res, Vol.69, No.6, pp. 2349-2357, (March 2009), ISSN 1538-7445

Schneider-Stock, R., Boltze, C., Peters, B., Szibor, R., Landt, O., Meyer, F. \& Roessner, A. (2004a). Selective loss of codon 72 proline p53 and frequent mutational inactivation of the retained arginine allele in colorectal cancer. Neoplasia, Vol.6, No.5, pp. 529535, (November 2004), ISSN 1522-8002

Schneider-Stock, R., Mawrin, C., Motsch, C., Boltze, C., Peters, B., Hartig, R., Buhtz, P., Giers, A., Rohrbeck, A., Freigang, B. \& Roessner, A. (2004b). Retention of the arginine allele in codon 72 of the p53 gene correlates with poor apoptosis in head and neck cancer. Am J Pathol, Vol.164, No.4, pp. 1233-1241, (March 2004), ISSN 0002-9440 
Schwartz, J.L., Plotnik, D., Slovic, J., Li, T., Racelis, M., Deeg, H.J. \& Friedman, D.L. (2011). TP53 codon-72 polymorphisms identify different radiation sensitivities to g2chromosome breakage in human lymphoblast cells. Environ Mol Mutagen, Vol.52, No.1, pp. 77-80, (November 2010), ISSN 1098-2280

Sergentanis, T.N. \& Economopoulos, K.P. (2010a). Eligible and not eligible studies in the recent meta-analysis about p53 polymorphism and breast cancer risk. Breast Cancer Res Treat, Vol.120, No.1, pp. 261-262, (September 2009), ISSN 1573-7217

Sergentanis, T.N. \& Economopoulos, K.P. (2010b). Latitude May modify the effect of TP53 codon 72 polymorphism on cancer risk. Cancer, Vol.116, No.14, pp. 3523, (June 2010), ISSN 0008-543X

Sergentanis, T.N. \& Economopoulos, K.P. (2011). Re: Jiang et al.: Meta-analysis of association between TP53 Arg72Pro polymorphism and bladder cancer risk (Urology 2010;76:765). Urology, Vol.77, No.1, pp. 259-260, (January 2011), ISSN 1527-9995

Seviour, E.G. \& Lin, S.Y. (2010). The DNA damage response: Balancing the scale between cancer and ageing. Aging (Albany NY), Vol.2, No.12, pp. 900-907, (December 2010), ISSN 1945-4589

Shi, H., Tan, S.J., Zhong, H., Hu, W., Levine, A., Xiao, C.J., Peng, Y., Qi, X.B., Shou, W.H., Ma, R.L., Li, Y., Su, B. \& Lu, X. (2009). Winter temperature and UV are tightly linked to genetic changes in the p53 tumor suppressor pathway in Eastern Asia. Am J Hum Genet, Vol.84, No.4, pp. 534-541, (April 2009), ISSN 1537-6605

Siddique, M. \& Sabapathy, K. (2006). Trp53-dependent DNA-repair is affected by the codon 72 polymorphism. Oncogene, Vol.25, No.25, pp. 3489-3500, (February 2006), ISSN 0950-9232

Siddique, M.M., Balram, C., Fiszer-Maliszewska, L., Aggarwal, A., Tan, A., Tan, P., Soo, K.C. \& Sabapathy, K. (2005). Evidence for selective expression of the p53 codon 72 polymorphs: implications in cancer development. Cancer Epidemiol Biomarkers Prev, Vol.14, No.9, pp. 2245-2252, (September 2005), ISSN 1055-9965

Sidhu, S., Martin, E., Gicquel, C., Melki, J., Clark, S.J., Campbell, P., Magarey, C.J., Schulte, K.M., Roher, H.D., Delbridge, L. \& Robinson, B.G. (2005). Mutation and methylation analysis of TP53 in adrenal carcinogenesis. Eur J Surg Oncol, Vol.31, No.5, pp. 549-554, (June 2005), ISSN 0748-7983

Sjalander, A., Birgander, R., Kivela, A. \& Beckman, G. (1995). p53 polymorphisms and haplotypes in different ethnic groups. Hum Hered, Vol.45, No.3, pp. 144-149, (May 1995), ISSN 0001-5652

Sjalander, A., Birgander, R., Saha, N., Beckman, L. \& Beckman, G. (1996). p53 polymorphisms and haplotypes show distinct differences between major ethnic groups. Hum Hered, Vol.46, No.1, pp. 41-48, (January 1996), ISSN 0001-5652

Soo, R.A., Loh, M., Mok, T.S., Ou, S.H., Cho, B.C., Yeo, W.L., Tenen, D.G. \& Soong, R. (2011). Ethnic differences in survival outcome in patients with advanced stage non-small cell lung cancer: results of a meta-analysis of randomized controlled trials. J Thorac Oncol, Vol.6, No.6, pp. 1030-1038, (May 2011), ISSN 1556-1380

Soussi, T. (2007). p53 alterations in human cancer: more questions than answers. Oncogene, Vol.26, No.15, pp. 2145-2156, (April 2007), ISSN 0950-9232 
Spielman, R.S., Bastone, L.A., Burdick, J.T., Morley, M., Ewens, W.J. \& Cheung, V.G. (2007). Common genetic variants account for differences in gene expression among ethnic groups. Nat Genet, Vol.39, No.2, pp. 226-231, (January 2007), ISSN 1061-4036

Storey, A., Thomas, M., Kalita, A., Harwood, C., Gardiol, D., Mantovani, F., Breuer, J., Leigh, I.M., Matlashewski, G. \& Banks, L. (1998). Role of a p53 polymorphism in the development of human papillomavirus-associated cancer. Nature, Vol.393, No.6682, pp. 229-234, (June 1998), ISSN 0028-0836

Szymanowska, A., Jassem, E., Dziadziuszko, R., Borg, A., Limon, J., Kobierska-Gulida, G., Rzyman, W. \& Jassem, J. (2006). Increased risk of non-small cell lung cancer and frequency of somatic TP53 gene mutations in Pro72 carriers of TP53 Arg72Pro polymorphism. Lung Cancer, Vol.52, No.1, pp. 9-14, (February 2006), ISSN 0169-5002

Tandle, A.T., Sanghvi, V. \& Saranath, D. (2001). Determination of p53 genotypes in oral cancer patients from India. Br J Cancer, Vol.84, No.6, pp. 739-742, (March 2001), ISSN 0007-0920

Tang, N.P., Wu, Y.M., Wang, B. \& Ma, J. (2010). Systematic review and meta-analysis of the association between P53 codon 72 polymorphism and colorectal cancer. Eur J Surg Oncol, Vol.36, No.5, pp. 431-438, (April 2010), ISSN 1532-2157

Testa, R., Bonfigli, A.R., Salvioli, S., Invidia, L., Pierini, M., Sirolla, C., Marra, M., Testa, I., Fazioli, F., Recchioni, R., March eselli, F., Olivieri, F., Lanari, L. \& Franceschi, C. (2009). The Pro/Pro genotype of the 553 codon 72 polymorphism modulates PAI-1 plasma levels in ageing. Mech Ageing Dev, Vol.130, No.8, pp. 497-500, (June 2009), ISSN 1872-6216

The Breast Cancer Association Consortium. (2006). Commonly studied single-nucleotide polymorphisms and breast cancer: results from the Breast Cancer Association Consortium. J Natl Cancer Inst, Vol.98, No.19, pp. 1382-1396, (October 2006), ISSN 1460-2105

Thiagalingam, S., Foy, R.L., Cheng, K.H., Lee, H.J., Thiagalingam, A. \& Ponte, J.F. (2002). Loss of heterozygosity as a predictor to map tumor suppressor genes in cancer: molecular basis of its occurrence. Curr Opin Oncol, Vol.14, No.1, pp. 65-72, (January 2002), ISSN 1040-8746

Thomas, M., Kalita, A., Labrecque, S., Pim, D., Banks, L. \& Matlashewski, G. (1999). Two polymorphic variants of wild-type p53 differ biochemically and biologically. Mol Cell Biol, Vol.19, No.2, pp. 1092-1100, (February 1999), ISSN 0270-7306

Truong, T., Sauter, W., McKay, J.D., Hosgood, H.D., 3rd, Gallagher, C., Amos, C.I., Spitz, M., Muscat, J., Lazarus, P., Illig, T., Wichmann, H.E., Bickeboller, H., Risch, A., Dienemann, H., Zhang, Z.F., Naeim, B.P., Yang, P., Zienolddiny, S., Haugen, A., Le March and, L., Hong, Y.C., Kim, J.H., Duell, E.J., Andrew, A.S., Kiyohara, C., Shen, H., Matsuo, K., Suzuki, T., Seow, A., Ng, D.P., Lan, Q., Zaridze, D., SzeszeniaDabrowska, N., Lissowska, J., Rudnai, P., Fabianova, E., Constantinescu, V., Bencko, V., Foretova, L., Janout, V., Caporaso, N.E., Albanes, D., Thun, M., Landi, M.T., Trubicka, J., Lener, M., Lubinski, J., Wang, Y., Chabrier, A., Boffetta, P., Brennan, P. \& Hung, R.J. (2010). International Lung Cancer Consortium: coordinated association study of 10 potential lung cancer susceptibility variants. Carcinogenesis, Vol.31, No.4, pp. 625-633, (January 2010), ISSN 1460-2180 
Tsuda, H. (2009). Gene and chromosomal alterations in sporadic breast cancer: correlation with histopathological features and implications for genesis and progression. Breast Cancer, Vol.16, No.3, pp. 186-201, (May 2009), ISSN 1880-4233

van Heemst, D., Mooijaart, S.P., Beekman, M., Schreuder, J., de Craen, A.J., Brandt, B.W., Slagboom, P.E. \& Westendorp, R.G. (2005). Variation in the human TP53 gene affects old age survival and cancer mortality. Exp Gerontol, Vol.40, No.1-2, pp. 1115, (March 2005), ISSN 0531-5565

Vannini, I., Zoli, W., Tesei, A., Rosetti, M., Sansone, P., Storci, G., Passardi, A., Massa, I., Ricci, M., Gusolfino, D., Fabbri, F., Ulivi, P., Brigliadori, G., Amadori, D. \& Bonafe, M. (2008). Role of p53 codon 72 arginine allele in cell survival in vitro and in the clinical outcome of patients with advanced breast cancer. Tumour Biol, Vol.29, No.3, pp. 145-151, (Jule 2008), ISSN 1423-0380

Vigneron, A. \& Vousden, K.H. (2010). p53, ROS and senescence in the control of aging. Aging (Albany NY), Vol.2, No.8, pp. 471-474, (August 2010), ISSN 1945-4589

Vousden, K.H. \& Prives, C. (2009). Blinded by the light: The growing complexity of p53. Cell, Vol.137, No.3, pp. 413-431, (May 2009), ISSN 1097-4172

Vousden, K.H. \& Ryan, K.M. (2009). p53 and metabolism. Nat Rev Cancer, Vol.9, No.10, pp. 691-700, (September 2009), ISSN 1474-1768

Wang, B., Wang, D., Zhang, D., Li, A., Liu, D., Liu, H. \& Jin, H. (2010a). Pro variant of TP53 Arg72Pro contributes to esophageal squamous cell carcinoma risk: evidence from a meta-analysis. Eur J Cancer Prev, Vol.19, No.4, pp. 299-307, (April 2010), ISSN 14735709

Wang, J.J., Zheng, Y., Sun, L., Wang, L., Yu, P.B., Dong, J.H., Zhang, L., Xu, J., Shi, W. \& Ren, Y.C. (2010b). TP53 codon 72 polymorphism and colorectal cancer susceptibility: a meta-analysis. Mol Biol Rep, (December 2010), DOI: 10.1007/s11033-010-0619-8, ISSN 1573-4978

Wang, Y., Kringen, P., Kristensen, G.B., Holm, R., Baekelandt, M.M., Olivier, M., Skomedal, H., Hainaut, P., Trope, C.G., Abeler, V.M., Nesland, J.M., Borresen-Dale, A.L. \& Helland, A. (2004). Effect of the codon 72 polymorphism (c.215G>C, p.Arg72Pro) in combination with somatic sequence variants in the TP53 gene on survival in patients with advanced ovarian carcinoma. Hum Mutat, Vol.24, No.1, pp. 21-34, (June 2004), ISSN 1098-1004

Wang, Y.C., Chen, C.Y., Chen, S.K., Chang, Y.Y. \& Lin, P. (1999). p53 codon 72 polymorphism in Taiwanese lung cancer patients: association with lung cancer susceptibility and prognosis. Clin Cancer Res, Vol.5, No.1, pp. 129-134, (January 1999), ISSN 1078-0432

Wegman, P.P., Marcus, N.J., Malakkaran, B.P. \& Wingren, S. (2009). Biological significance of allele specific loss of the p53 gene in breast carcinomas. Breast Cancer Res Treat, Vol.118, No.1, pp. 15-20, (October 2008), ISSN 1573-7217

Weston, A., Pan, C.F., Ksieski, H.B., Wallenstein, S., Berkowitz, G.S., Tartter, P.I., Bleiweiss, I.J., Brower, S.T., Senie, R.T. \& Wolff, M.S. (1997). p53 haplotype determination in breast cancer. Cancer Epidemiol Biomarkers Prev, Vol.6, No.2, pp. 105-112, (February 1997), ISSN 1055-9965 
Whibley, C., Pharoah, P.D. \& Hollstein, M. (2009). p53 polymorphisms: cancer implications. Nat Rev Cancer, Vol.9, No.2, pp. 95-107, (January 2009), ISSN 1474-1768

Wilentz, R.E., Argani, P. \& Hruban, R.H. (2001). Loss of heterozygosity or intragenic mutation, which comes first? Am J Pathol, Vol.158, No.5, pp. 1561-1563, (May 2001), ISSN 0002-9440

Willman, C.L. \& Hromas, R.A. (2010). Genomic alterations and chromosomal aberrations in human cancer, In: Holland Frei Cancer Medicine, W.K. Hong et al., (Ed.), 104-132, People's Medical Publishing House-USA, ISBN 1607950146, Shelton, USA

Wu, X., Zhao, H., Amos, C.I., Shete, S., Makan, N., Hong, W.K., Kadlubar, F.F. \& Spitz, M.R. (2002). p53 genotypes and haplotypes associated with lung cancer susceptibility and ethnicity. J Natl Cancer Inst, Vol.94, No.9, pp. 681-690, (May 2002), ISSN 00278874

Yan, L., Zhang, D., Chen, C., Mao, Y., Xie, Y., Li, Y., Huang, Y. \& Han, B. (2009). TP53 Arg72Pro polymorphism and lung cancer risk: a meta-analysis. Int J Cancer, Vol.125, No.12, pp. 2903-2911, (Jule 2009), ISSN 1097-0215

Zhang, B., Beeghly-Fadiel, A., Long, J. \& Zheng, W. (2011a). Genetic variants associated with breast-cancer risk: comprehensive research synopsis, meta-analysis, and epidemiological evidence. Lancet Oncol, Vol.12, No.5, pp. 477-488, (April 2011), ISSN 1474-5488

Zhang, J., Zhuo, W.L., Zheng, Y. \& Zhang, Y.S. (2010a). Polymorphisms of TP53 codon 72 with prostate carcinoma risk: a meta-analysis. Med Oncol, Vol.27, No.2, pp. 540-546, (June 2009), ISSN 1559-131X

Zhang, L., Shao, N., Yu, Q., Hua, L., Mi, Y. \& Feng, N. (2011b). Association between p53 Pro72Arg polymorphism and prostate cancer risk: a meta-analysis. Journal of Biomedical Research, Vol.25, No.1, pp. 25-32, (January 2011)

Zhang, Z., Fu, G., Wang, M., Tong, N., Wang, S. \& Zhang, Z. (2008). P53 codon 72 polymorphism and ovarian cancer risk: a meta-analysis. Journal of Nanjing Medical University, Vol.22, No.5, pp. 279-285, (September 2008)

Zhang, Z., Wang, M., Wu, D., Tong, N. \& Tian, Y. (2010b). P53 codon 72 polymorphism contributes to breast cancer risk: a meta-analysis based on 39 case-control studies. Breast Cancer Res Treat, Vol.120, No.2, pp. 509-517, (Jule 2009), ISSN 1573-7217

Zhao, Y., Wang, F., Shan, S., Qiu, X., Li, X., Jiao, F., Wang, J. \& Du, Y. (2010). Genetic polymorphism of p53, but not GSTP1, is association with susceptibility to esophageal cancer risk - a meta-analysis. Int J Med Sci, Vol.7, No.5, pp. 300-308, (September 2010), ISSN 1449-1907

Zhu, F., Dolle, M.E., Berton, T.R., Kuiper, R.V., Capps, C., Espejo, A., McArthur, M.J., Bedford, M.T., van Steeg, H., de Vries, A. \& Johnson, D.G. (2010). Mouse models for the p53 R72P polymorphism mimic human phenotypes. Cancer Res, Vol.70, No.14, pp. 5851-5859, (Jule 2010), ISSN 1538-7445

Zhu, Y., Wang, J., He, Q. \& Zhang, J.Q. (2011). Association of p53 codon 72 polymorphism with prostate cancer: a meta-analysis. Mol Biol Rep, Vol.38, No.3, pp. 1603-1607, (September 2010), ISSN 1573-4978 
Zhuo, W., Zhang, Y., Xiang, Z., Cai, L. \& Chen, Z. (2009a). Polymorphisms of TP53 codon 72 with breast carcinoma risk: evidence from 12226 cases and 10782 controls. J Exp Clin Cancer Res, Vol.28, pp. 115, (August 2009), ISSN 1756-9966

Zhuo, X.L., Cai, L., Xiang, Z.L., Zhuo, W.L., Wang, Y. \& Zhang, X.Y. (2009b). TP53 codon 72 polymorphism contributes to nasopharyngeal cancer susceptibility: a metaanalysis. Arch Med Res, Vol.40, No.4, pp. 299-305, (Jule 2009), ISSN 1873-5487

Zhuo, X.L., Li, Q., Zhou, Y., Cai, L., Xiang, Z.L., Yuan, W. \& Zhang, X.Y. (2009c). Study on TP53 codon 72 polymorphisms with oral carcinoma susceptibility. Arch Med Res, Vol.40, No.7, pp. 625-634, (January 2010), ISSN 1873-5487 


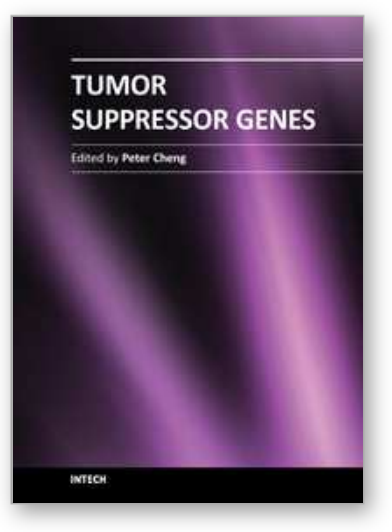

\author{
Tumor Suppressor Genes \\ Edited by Dr. Yue Cheng
}

ISBN 978-953-307-879-3

Hard cover, 332 pages

Publisher InTech

Published online 03, February, 2012

Published in print edition February, 2012

Functional evidence obtained from somatic cell fusion studies indicated that a group of genes from normal cells might replace or correct a defective function of cancer cells. Tumorigenesis that could be initiated by two mutations was established by the analysis of hereditary retinoblastoma, which led to the eventual cloning of RB1 gene. The two-hit hypothesis helped isolate many tumor suppressor genes (TSG) since then. More recently, the roles of haploinsufficiency, epigenetic control, and gene dosage effects in some TSGs, such as P53, P16 and PTEN, have been studied extensively. It is now widely recognized that deregulation of growth control is one of the major hallmarks of cancer biological capabilities, and TSGs play critical roles in many cellular activities through signaling transduction networks. This book is an excellent review of current understanding of TSGs, and indicates that the accumulated TSG knowledge has opened a new frontier for cancer therapies.

\title{
How to reference
}

In order to correctly reference this scholarly work, feel free to copy and paste the following:

Evgeny V. Denisov, Nadezhda V. Cherdyntseva, Nicolay V. Litviakov, Elena A. Malinovskaya, Natalya N. Babyshkina, Valentina A. Belyavskaya and Mikhail I. Voevoda (2012). TP53 Gene Polymorphisms in Cancer Risk: The Modulating Effect of Ageing, Ethnicity and TP53 Somatic Abnormalities, Tumor Suppressor Genes, Dr. Yue Cheng (Ed.), ISBN: 978-953-307-879-3, InTech, Available from:

http://www.intechopen.com/books/tumor-suppressor-genes/tp53-gene-polymorphisms-in-cancer-risk-themodulating-effect-of-ageing-ethnicity-and-tp53-somatic-ab

\section{INTECH}

open science | open minds

\section{InTech Europe}

University Campus STeP Ri

Slavka Krautzeka 83/A

51000 Rijeka, Croatia

Phone: +385 (51) 770447

Fax: +385 (51) 686166

www.intechopen.com

\section{InTech China}

Unit 405, Office Block, Hotel Equatorial Shanghai

No.65, Yan An Road (West), Shanghai, 200040, China 中国上海市延安西路65号上海国际贵都大饭店办公楼 405 单元

Phone: +86-21-62489820

Fax: $+86-21-62489821$ 
(C) 2012 The Author(s). Licensee IntechOpen. This is an open access article distributed under the terms of the Creative Commons Attribution 3.0 License, which permits unrestricted use, distribution, and reproduction in any medium, provided the original work is properly cited. 